\title{
Adam Kubiś
}

\author{
The John Paul II Catholic University of Lublin \\ ORCID: 0000-0003-4961-2254
}

\section{The Creation Theme in the Gospel of John ${ }^{1}$}

\begin{abstract}
The article surveys recent scholarship on the use of creation imagery in the Gospel of John, with the aim of presenting a rather exhaustive register of possible references. Both the obvious and the less clear-cut allusions to Gen 1-3 are discussed, the main focus being to accumulate and assess the evidence (for or against) all the apparent references to creation imagery. Included in this examination are several unconvincing and even far-fetched proposals advanced by some modern scholars, in order to give the fullest possible picture of the current discourse on these issues. After discussing the creation theme in the Prologue (1:1-18), the article explores the presence of creation imagery in the Book of Signs (1:19-12:50) and the Book of Glory (13:1-21:25).
\end{abstract}

Keywords: Gospel of John, creation, new creation, NT use of the OT, intertextuality

\section{Introduction}

$\mathrm{T}$ The Epistles of St Paul present the notion of the "new creation",

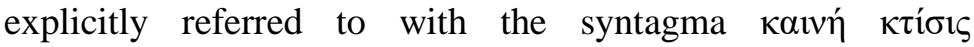
(2 Cor 5:17; Gal 6:15). Even though that specific phrase does not occur in the Gospel of John, the same concept of creation, conceived of as rejuvenation or re-creation, is found there as well. In John, however, it is more veiled, typically concealed within allusions which oftentimes prove difficult to identify. Among the early

${ }^{1}$ This article is a revised version of my previous study published in Polish: Adam Kubiś, "Temat stworzenia w Ewangelii Janowej," Collectanea Theologica 88 (2018) no. 3, 5-38. 
Christian writers, it was a common practice to read these allusions to the creation theme in the Fourth Gospel, hence the Church Fathers left rich oeuvre identifying Johannine allusions to Gen 1-3. Interestingly, in the modern period it was only the British scholar Sir Edwin Clement Hoskyns who, with his 1920 article, drew the attention of his contemporaries reading the Fourth Gospel to the rich symbolism of creation applied in the Passion of Jesus and His resurrection. ${ }^{2}$ Almost a century after that pioneering article by Hoskyns, many other important articles have now been written, and at least two monographs, discussing the allusions to Gen 1-3 not only in John 19-20 but throughout that entire Gospel. ${ }^{3}$ The limited scope of this paper means that it is a survey, introductory in nature, and, as such, not intended as an exhaustive treatment or in-depth analysis of every possible example of the motif of creation in the Gospel of John. The work's purpose is rather to serve as a guide, signalling the wealth and diversity of allusions to the theme of creation in the text of the Fourth Gospel.

Due to the lack of clear, direct citations of Gen 1-3 in the Johannine narrative, i.e., marked with a quotation formula, we will limit ourselves to the allusions, omitting (with a few exceptions) the intertextual phenomenon referred to as an echo. ${ }^{4}$ As for

${ }^{2}$ E.C. Hoskyns, Genesis I-III and St John's Gospel, The Journal of Theological Studies 21 (1920): 210-18.

3 A.M. Moore, Signs of Salvation. The Theme of Creation in John's Gospel, (Cambridge 2013); C.R. Sosa Siliezar, Creation Imagery in the Gospel of John, Library of New Testament Studies 546 (London 2015). One should also mention here the unpublished work by T.C. Voortman, Understanding the Fourth Gospel from the Perspective of the Creation Theme (Ph.D. diss., Rand Afrikaans University, 1998).

${ }^{4}$ C.R. Sosa Siliezar, Creation, 11, argues against speaking of allusions and echos, instead adopting the notion of creation imagery, the reason being the symbolic and sensory (sensuous) nature of the Gospel of John, one that implies a descriptive and figurative language. However, we believe that the distinction of allusions and echos-falling back on the listener's/reader's ability to transfer the discovered hypo-text (Gen 1-3) into a new interpretation of the hyper-text (John) - to remain valid. If the hypo-text influences the interpretation of the hyper-text, then we call the resultant phenomenon an allusion. If no such influence is found, we are dealing with an echo. For more on the methodological matters related to the intertextual research on the Fourth Gospel, see A. Kubiś, The Book of Zechariah in the Gospel of John, Études bibliques 64, (Pendé 2012), 21-5. 
the methodological principles behind the presentation which follow, four basic criteria should be noted which help us identify the allusions to Gen 1-3 in the text of the Gospel of John. The first of these will be the similarity between the hypo-text (Gen 1-3) and the hyper-text (the Gospel of John) in terms of their terminology (even a single word), syntax, imagery, theme, and context. The second criterion is that of discontinuity, whether in grammar or in the narrative (logic). The third is John's principle of double entendre, understood as the deliberately equivocal nature of many Johannine terms and phrases. ${ }^{5}$ The fourth criterion will be the history of interpretation, since many of the allusions had already been identified in antiquity and thus became integrated into the history of the exegesis of given Johannine passages. So, in discovering and exploring the allusions, we will refer to the findings of both ancient and contemporary exegetes. ${ }^{6}$ As noted, this presentation will include only a selection of allusions, without claiming to be an exhaustive compendium of all the proposals put forth throughout the centuries. When identifying allusions, a prudent level of criticism is called for, since many suggestions advanced from a weak methodological basis bear the marks of ungrounded over-interpretations. In short, proposals deemed extremely hypothetical in nature have been omitted. ${ }^{7}$ Because of the confusion

5 See G. van Belle, Double Entendre in the Gospel according to John, in G. van Belle, J.G. van der Watt, P. Maritz, eds., Theology and Christology in the Fourth Gospel. Essays by the Members of the SNTS Johannine Writings Seminar, BETL 184; (Leuven 2005), 463-81; E. Richard, Expressions of Double Meaning and Their Function in the Gospel of John, New Testament Studies 31 (1985): 69-112.

${ }^{6}$ More on the above and other criteria useful in identification of allusions, see R.B. Hays, Echoes of Scripture in the Letters of Paul, (New Haven, CT 1989), 29-32; idem, The Conversation of the Imagination. Paul as Interpreter of Israel's Scripture, (Grand Rapids 2005), 34-45; M.B. Thompson, Clothed with Christ. The Example and Teaching of Jesus in Romans 12.1-15.13, JSNT.S 59, (Sheffield 1991), 31-6; B.S. Rosner, Paul, Scripture and Ethics: A Study of 1 Corinthians 5-7, AJEC 22, (Leiden 1994), 17-20; D. Allen, The Use of Criteria: The State of the Question, in D. Allen, S. Smith, eds., Methodology in the Use of the Old Testament in the New: Context and Criteria, LNTS 579, (London 2019), 129-141.

${ }^{7}$ Regarding the subjectivity of the process of discovering and analysing intertextual references, see M. Jauhiainen, The Use of Zechariah in Revelation, WUNT II/199, 
in applying the criteria for distinguishing an allusion from an echo, there is truly no opinio communis regarding the number of intertextual references to Gen 1-3 in the Fourth Gospel, and, consequently, little consensus even as to the importance of such evocations in the Johannine narrative. There is only unanimity as to the actual presence of the creation theme in the Fourth Gospel as such, particularly in the Prologue, in the High Priestly Prayer, and in John 20:22.

In this paper, the presentation of the various allusions has been organized according to the framework imposed by the structure of John's Gospel itself. First, there will be a treatment of the references to Gen $1-3$ in the Johannine Prologue (1:1-19), then of those found in the Book of Signs (1:19-12:50), and finally references from the Book of Glory (12:1-21:25).

\section{The Prologue}

Starting from Origen (Comm. Jo. 2.36), numerous commentators, from antiquity to the present day, have treated the opening words of the Gospel of John, $\dot{\varepsilon} v \dot{\alpha} \rho \chi \tilde{\eta}$, as an allusion to the first sentence in the Genesis, as translated in the Septuagint. In both

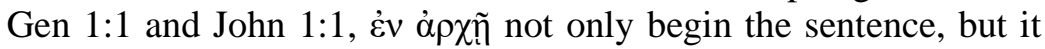

(Tübingen 2005), 34: "Depending primarily on their competence, some readers perceive an allusion, others see only an echo, while yet others may not discern a reference to the OT at all. The best approximation to objectivity is the normal scholarly debate to which all interpretations are subjected. The key issue is not how we discover or identify allusions, but rather how we are able to argue that our reading of the text makes the most sense." He also states (ibid., 36): "The key task of an interpreter is to offer a satisfying account of how the proposed allusion contributes to the context where it has been placed. The degree of objectivity can subsequently be increased by submitting this account to the scrutiny of the scholarly community." In the same vein, he concludes his study (ibid., 164): "It is primarily a matter of being a competent reader and sharing enough of the author's presuppositions so that the allusions will be actualised the way the author intended. Thus, while some of the criteria proposed in earlier studies may be helpful, especially in drawing the interpreter's attention to the variety of possible manifestations of allusions, their systematic application is no guarantee of objective results. We demonstrated the subjective nature of the study of allusions by comparing three studies, where all claimed to have used precise criteria, but whose results were quite different even when the same criteria had been followed." 
also opens the entire book. In both cases, it is the narrator speaking. In both, their subject is the beginning of the world. Moreover, the larger phrases proceed to demonstrate a similarity both in how they sound and a parallelism in their order of words: $\dot{\varepsilon} v \dot{\alpha} \rho \chi \tilde{n}$ (prefacing a sentence at the beginning of the book) + verb ( $\dot{\varepsilon} \pi$ oín $\sigma \varepsilon v / \tilde{\eta} v-\eta$ and $v$ are common) + the article $\dot{o}+$ two-syllable subject with two vowels ending in $-o \varsigma(\theta \varepsilon o ́ \varsigma / \lambda o ́ \gamma o \varsigma){ }^{8}$

The Prologue also features other allusions to Gen $1-3$. The theme of creation is directly apparent in 1:3 and 1:10. The subjects of

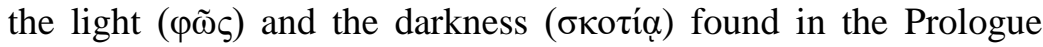
(1:4-5) are likewise present in the account of creation in Gen 1 (2-5.14-18). ${ }^{9}$ In addition, the term $\lambda$ ó $\gamma \circ \varsigma$, used four times and crucial for the Johannine Prologue, evokes the nine instances of the phrase "God said" ( $\varepsilon \tilde{i} \pi \varepsilon v$ o $\theta \varepsilon$ ó $)$ ) repeated throughout the narrative of creation in Gen 1. This intuition appears to be correct, as the image of God creating the world through his $\lambda$ ó $\gamma$ o $\varsigma$ can also be found in Ps 32:6, Wis 9:1, Targum Neofiti to Gen 1:1-2:2, and in many ancient extra-biblical Jewish and Christian texts. ${ }^{10}$ The words

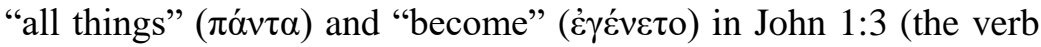
three times) are also frequently used in Gen 1:1-2:7. It was already John Chrysostom (Hom. Jo. 5.1) who pointed out the Johannine indication that everything happened because of God's $\lambda$ ó $\gamma$ os (1:3) as an allusion to the notion of everything having been created by God in Gen 1-2. The motif of life ( $\zeta \omega \eta$ ), appearing in the Prologue

\footnotetext{
${ }^{8}$ As indicated by D.C. Allison, The New Moses. A Matthean Typology, (Edinburgh 1993), 20.

${ }^{9}$ For more on the subject of light in the Prologue in connection with Gen 1, see P. Borgen, Logos Was the True Light. Contributions to the Interpretation of the Prologue of John, Novum Testamentum 14 (1972): 115-30. See also M.M. Thompson, "Light" ( $\varphi \tilde{\omega} \varsigma)$ : The Philosophical Content of the Term and the Gospel of John, in J.G. van der Watt, R.A. Culpepper, U. Schnelle, eds., The Prologue of the Gospel of John: Its Literary, Theological and Philosophical Contexts, WUNT 359, (Tübingen 2016), 273-83; D. Piekarz, “A światłość w ciemności świeci...”. Konfrontacja świattości z ciemnościa w Ewangelii Janowej ["The light shines in the darkness..." The Confrontation of Light with Darkness in the Gospel of John], Verbum Vitae 29 (2016) 251-69.

10 The entire list of these has been compiled by M. Endo, Creation and Christology. A Study on the Johannine Prologue in the Light of Early Jewish Creation Accounts, WUNT 2/149, (Tübingen 2002), 210.
} 
alongside the themes of light ( $\varphi \tilde{\omega} \varsigma)$, shining ( $\varphi \alpha i v \omega)$, and darkness

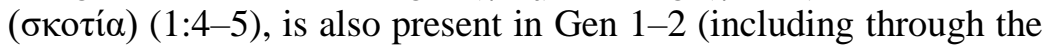
application of other semantically related terms, such as $\varphi \omega \sigma \tau \eta ́ \rho-$ star, and $\varphi \alpha \tilde{v} \sigma 1 \varsigma$ - light[ness]). The Prologue also introduces the idea of "God's children" ( $\tau \dot{\varepsilon} \kappa v \alpha \theta \varepsilon \circ \tilde{v}-1: 12$ ) who are "begotten by God"

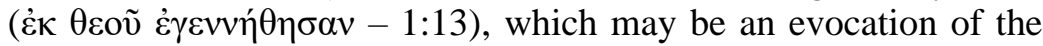
image of Adam and Eve, who originated directly from God. Juan Mateos and Juan Barreto claim that the entire set of terms related to

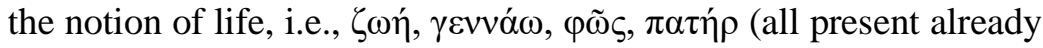

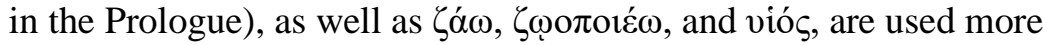
frequently in John than in any other of the canonical Gospels, with the notion of creation serving as its interpretative background. ${ }^{11}$ John McHugh believes that the three-phrase structure of the sentence in John 1:10 corresponds to the narrative logic pervading Gen 1-3. The world was created through o $\lambda$ óyos, therefore the

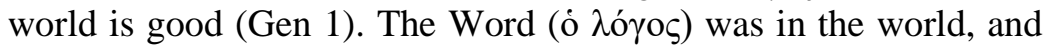
hence it called the world to celebrate the fullness of happiness

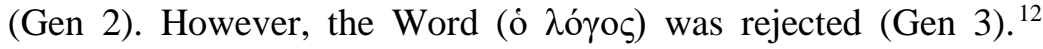
Additionally, Paul S. Minear suggests that the expression "grace and

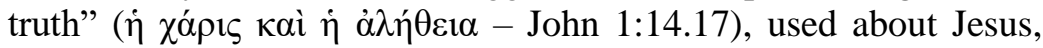
points to his mission of opening the path to the situation described in Gen 1-2. The triple negation in John 1:13 ("not of blood, nor of the will of the flesh, nor of the will of man") alludes to the removal of the curse inflicted upon the woman in Gen 3:16. ${ }^{13}$ Mary Coloe also believes that the structure of John 1:1-18 refers to the structure of Gen 1:1-2:4a. While the account in Gen 1 ends with the culmination on the seventh day, when God completed his work of creation, the structure of the Johannine Prologue does not feature any such climax, pointing instead to the work of Christ, described in the subsequent part of the Gospel, as the deed completing the work

11 J. Mateos, J. Barreto, Dizionario teologico del Vangelo di Giovanni, (Assisi 1982), 56-7. This list should be extended to include the specifically Johannine

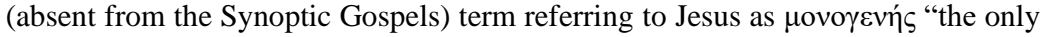
begotten" (1:14.18; 3:16.18).

12 J.F. McHugh, A Critical and Exegetical Commentary on John 1-4, The International Critical Commentary, (London 2009), 40-1.

13 P.S. Minear, Christians and the New Creation. Genesis Motifs in the New Testament, (Louisville 1994), 83-5, 92-3, 100. 
of the Father. ${ }^{14}$ Also of importance is the thematic inclusio related to life featured in the Gospel of John. At the outset of the narrative, it is said that Jesus is life (1:4; see 14:6). Meanwhile, it concludes with the declaration that the objective for which the Gospel had been written is to induce faith, giving one nothing else but life itself (20:32; see 3:15.16). Furthermore, in the Gospel of John the notion of life ( $\zeta \omega \eta$ - thirty-six instances) is oftentimes qualified as eternal

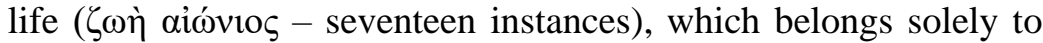
God and those united with him through faith. Consequently, in the Johannine theology the notion of life is associated with the resurrection (see 11:25). Significantly, the ideas of resurrection and of the restoration of the creation were inextricably intertwined in the Judaism of the time of Jesus, for the eschatology of the Judaism of that period awaited a universal resurrection and a resultant renewal of the entire creation. ${ }^{15}$ Within Johannine theology, it is the risen Jesus who possesses eternal life, which may also be entered into by those believing in Him. In that sense, everyone who believes in Jesus, by being granted eternal life, simultaneously experiences the restoration of the creation. ${ }^{16}$

According to Carlos R. Sosa Siliezar, the themes of creation in the Johannine Prologue have been used in a three-fold way: "First, John intended to portray the Word/Jesus in close association with God existing apart from and prior to the created order in a relationship that legitimizes his participation in divine activities. Second, John asserts the primal and universal significance of the Word/Jesus and privileges him over John [the Baptist] and Moses. Third, John uses creation imagery to link past reality with present

${ }^{14}$ M. Coloe, The Structure of the Johannine Prologue and Genesis 1, Australian Biblical Review 45 (1997): 52-4. This approach was criticised in C.R. Sosa Siliezar, Creation, 42-3.

15 G.K. Beale, The Eschatological Conception of New Testament Theology, in K.E. Brower, M.W. Elliott, eds., Eschatology in Bible and Theology. Evangelical Essays at the Dawn of a New Millennium, (Downers Grove, IL 1997), 19: "New creation is in mind whenever the concept of resurrection occurs, since it is essentially the new creation of humanity." Cf. N.T. Wright, Resurrection and the Renewal of Creation, The Biblical Annals 9/4 (2019): 655-70.

${ }^{16}$ More on the subject of the Johannine concept of life as the motif of the restored creation in J.K. Brown, Creation's Renewal in the Gospel of John, The Catholic Biblical Quarterly 72 (2010): 277-8. 
and future reality, portraying the Word/Jesus as the agent of creation who is to be regarded as the privileged agent of revelation and redemption as well." 17

There can be no doubt about the prominence given to the theme of creation within the overall plan of the Gospel. By commencing his narrative with an unmistakable reference to the account of creation in Gen 1-3, John provides the reader with the key to reading the event of Jesus Christ. In other words, the Johannine story of Jesus ought to be interpreted in light of the creation theme. ${ }^{18}$ After the theme of the Passover Covenant, this appears to be the thematic axis second in importance in the entire Gospel. ${ }^{19}$ By opening the Gospel in the same way as the first book of the Torah, and of the Bible itself, John is most likely suggesting to his readers that his work will be the new Torah, or even the new Bible. ${ }^{20}$

\section{The Book of Signs}

\subsection{Structure}

Some exegetes see the first scenes of the Gospel (1:19-2:11) as a seven-day scheme, which consequently would be a reference to the first week of creation in Gen 1-2: day one - the testimony of John the Baptist (1:19-28); day two - "Here is the Lamb of God" (1:2934); day three - the calling of Andrew and his companion (1:35-39); day four - the calling of Simon Peter (1:40-42); day five - the calling of Philip (1:43-46); day six - the calling of Nathanael

${ }^{17}$ C.R. Sosa Siliezar, Creation, 55.

18 J.K. Brown, Creation's Renewal, 277. The author speaks of the "centrality of creation as the context from which he [John] will tell his story of Jesus." T.C. Voortman, Understanding, 1, claims that one ought to read the Gospel of John "with the creation theme constantly in mind."

${ }^{19}$ J. Mateos, J. Barreto, Dizionario, 56: "Questa della creazione è una delle due linee portanti della teologia del vangelo di Gv; la seconda è quella della Pasquaalleanza."

${ }^{20}$ This thesis was put forth in M.J.J. Menken, Genesis in John's Gospel and 1 John, in S. Moyise, M.J.J. Menken, eds., Genesis in the New Testament, LNTS 466, (London 2012), 89. 
(1:47-51); day seven - the nuptials of Cana $(2: 1-11){ }^{21}$ The above division is not the only one proposed by exegetes, for the text of the Gospel does not provide markers clear enough for us to unequivocally separate out each of the seven days. For example, W.F. Hambly and L. Paul Trudinger claim that 2:12 speaks of the seventh day, understood as the day of Jesus' rest (Sabbath) after the miracle at Cana. ${ }^{22}$ However, unconvincing attempts have been made at treating the Prologue as a description of the first day of the new creation $^{23}$, or to situate the account of the miracle at Cana on the eight day. ${ }^{24}$ Whereas the attempts at discerning in 1:19-2:12 the seven days of creation come off as implausible, it is the six-day scheme presented directly in the text that seems to provide a reasonable key to interpretation.

${ }^{21}$ E.-B. Allo, L'Évangile spirituel de saint Jean suivi de le Règne de Dieu et le Monde, (Paris 1944), 75-6; F. Quiévreux, La structure symbolique de l'Évangile de Saint Jean, Revue d'histoire et de philosophie religieuses 33/2 (1953): 123-65; T. Barrosse, The Seven Days of the New Creation in St. John's Gospel, The Catholic Biblical Quarterly 21 (1959): 507-16.

${ }^{22}$ See W.F. Hambly, Creation and Gospel. A Brief Comparison of Genesis 1,1-2,4 and John 1,1-2,12, in F.L. Cross, ed., Studia Evangelica. V. Papers Presented to the Third International Congress on the New Testament Studies Held at Christ Church, Oxford, 1965, (Berlin 1968), 69-74; L.P. Trudinger, The Seven Days of the New Creation in St. John's Gospel: Some Further Reflections, Evangelical Quarterly 44 (1972): 154-9.

${ }^{23}$ For instance J. Willemse, Het vierde evangelie. Eeen onderzoek naar zijn structuur, (Hilversum-Antwerp 1965), 151-7.

${ }^{24}$ For instance P.W. Skehan, The Date of the Last Supper, Catholic Biblical Quarterly 20 (1958): 197-8; P. Van Diemen, La semaine inaugurale et la semaine terminale de l'Évangile de Jean. Message et structures, (Ph.D. diss., Rome 1972), vol. 1, 63-76. Various attempts at temporal ordering of the first two chapters of the Gospel of John have been discussed by A. Serra, Contributi dell'antica letteratura giudaica per l'esegesi di Giovanni 2, 1-12 e 19, 25-27, Scripta Pontificiae Facultatis Theologicae «Marianum» 31, (Roma 1977), 29-44; H. Saxby, The Time-Scheme in the Gospel of John, Expository Times 104 (1992): 9-13. Regarding the problem of

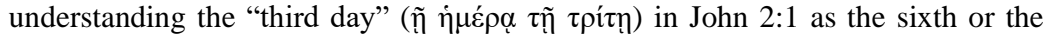
seventh day, see. T.E. Phillips, "The Third Fifth Day?" John 2:1 in Context, Expository Times 115 (2004): 328-31. Critical discussion and refutation of the thesis of an intertextual reference between the first week of creation in Gen 1-2 and the first week of Jesus' activity in the Gospel of John is provided in C.R. Sosa Siliezar, Creation, 123-30. 
There have also been proposals put forth to treat the entire Fourth Gospel as a symbolic structure evoking the seven days of creation. ${ }^{25}$ According to Juan Mateos and Juan Barreto, for example, the sixth day, which opens with the miracle of Cana, lasts until the moment of Jesus' death, who does indeed die on Friday, i.e. on the sixth day. The day of the Resurrection, after the Sabbath, is therefore the first day of the new creation (20:1-31). Thus, the entirety of the public ministry of Jesus, from the miracle of Cana until His death (2:1-19:42) is performed "under the sign" (el signo) "of the sixth day." ${ }^{26}$ Within the same symbolic key of the first week of creation, Marie-Émile Boismard, and others following him, dissect the Gospel of John into seven parts, corresponding to the seven days of creation, of which the first three serve to distinguish between the old and the new economies and the other three to "populate" the world with light and life: day one - the gift of the Spirit (1:29-34), and the new wine (2:1-11); day two - the new temple (2:13-21), the new birth (3:3-21), and the new cult (4:20-24); day three - the new Sabbath of God's work (John 5) and the new manna (John 6); day four - the Light of the World (John 7-9); day five - the new life (John 10-11); day six - the maturation of the new man (John 12-19); day seven - the new creation (John 20). ${ }^{27}$ These proposals, in spite

${ }^{25}$ Another proposal is to only frame John 1-5 in reference to the seven days in Gen 1-2. See C.M. Carmichael, The Story of Creation. Its Origins and Its Interpretation in Philo and the Fourth Gospel, (Ithaca 1996), 41-126: day one - John 1:15-42; day two - 1:43-51; day three $-2: 1-12$; day four $-2: 13-3: 21$; day five $-3: 22-36$; day six $-4: 1-54$; day seven $-5: 1-47$.

${ }^{26} \mathrm{~J}$. Mateos, J. Barreto, El Evangelio de Juan. Análisis lingüístico y comentario exegético, Lectura del Nuevo Testamento 4, (Madrid 1982), 15: "El tema de la creación, que se abre en el prologo $(1,1 \mathrm{ss})$, domina la cronología y da una clave de interpretación de la obra de Jesús. (...) De ahí que toda actividad de Jesús, hasta su muerte, quede bajo el signo de el día sexto, indicando el designio que la preside: dar remate a la obra creadora, completando al hombre con el Espíritu de Dios (cf. 19:30; 20:22)." The commentators divide "the sixth day" characteristic of the period of Jesus' public activity into "the day of the Messiah" (2:1-11:54) and the "final hour" of the sixth day, i.e., the Passover of the Messiah (11:55-19:42).

${ }^{27}$ M.-É. Boismard, L'évangile à quatre dimensions, Lumière 5/1 (1951): 94-114; idem, Le Prologue de Saint Jean, Lectio Divina 11, (Paris 1953), 137-8. See M. Girard, La structure heptapartite du quatrième évangile, Sciences Religieuses 5 (1975-1976): 350-9; J. Goettmann, Saint Jean. Évangile de la Nouvelle Genèse, 
of their symbolical attractiveness, have not been embraced by exegetes, the main objection being the artificial subordination of the text to a preconceived thesis. ${ }^{28}$

\subsection{Jesus' Signs and Works}

The number of the seven signs discovered in the Book of Signs is regarded by some exegetes as a reference to the seven days of creation in Gen 1-2. These signs are: (1) the turning of water into wine at Cana (2:1-11), (2) the healing of the royal official's son (4:46-54), (3) the healing of the paralytic in Jerusalem (5:1-9), (4) the feeding of the multitude $(6: 1-15)$, (5) Jesus' walking on the sea $(6: 16-21)$, (6) the healing of the man born blind $(9: 1-7)$, and (7) the raising of Lazarus (11:1-44). The resurrection of Jesus ought to be seen as the eight sign, announced already - with the use of the

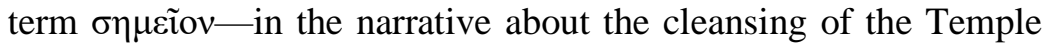

(Paris 1982). In his subsequent commentary, M.-É. Boismard modified his proposal, speaking of the structure of eight "weeks," preceded by an introduction (1:1-18) and concluding with an epilogue (21:1-25). Each of the symbolic "weeks" comprises a festival and/or a miraculous sign: week one - no festival, the sign at Cana (1:19-2:12); week two - the first Passover and the healing of a child in Capernaum (2:13-4:54); week three - the second Passover and the feeding of the five thousand $(6: 1-71)$; week four - Pentecost and the healing of the paralytic (5:1-47); week five - the Feast of Tabernacles and the healing of the man born blind (7:1-10:21); week six - the Festival of Lights and the raising of Lazarus (10:22-11:54); week seven - the third Passover and no sign (11:55-19:42); week eight - no festival and the sign of Jesus' Resurrection (20:1-31). During the seventh week, Jesus does not work and, therefore, does not perform a sign, for the week is to correspond to the Sabbath rest. The sign of walking on water is merely the effect of transferring certain elements of the Christophany from John 20-21 to John 6, in order to align the narrative to that of the Synoptic Gospels. See M.-É. Boismard, A. Lamouille, L'évangile de Jean, Synopse des quatre Évangiles en français 3, (Paris 1977), 39 and 44.

${ }^{28}$ A convincing critique of the approach based on the sixth days has been presented by G. Mlakuzhyil, The Christocentric Literary Structure of the Fourth Gospel. Second Enlarged Edition, Analecta Biblica 117, (Rome 2011), 74-5. The same author (80-1) also presents a critical comparison between both structures by M.-É. Boismard. 
$(2: 18-19) .{ }^{29}$ However, the various attempts to associate each of the above signs with the respective days of creation do not seem plausible. $^{30}$

In many passages of the Fourth Gospel, Jesus is presented as the one performing "works" ( $\tau \grave{\alpha}$ है $\rho \gamma \alpha) .{ }^{31}$ The works of Jesus $(10: 38)$ are described as the works of the Father (4:34; 5:36; 9:3-4; $10: 25.32 .37)$, for the Father is in Jesus and Jesus is in the Father $(10: 38 ; 14: 10.11$; cf. 10:30). Ultimately, it is the Father who does his works through Jesus (14:10). Such works will also be performed by the disciples (14:12), by virtue of the Father, Son, and the Spirit of the Paraclete living within them. Three texts in particulari.e., 4:34, 5:36, and 10:32 - display the typical vocabulary present

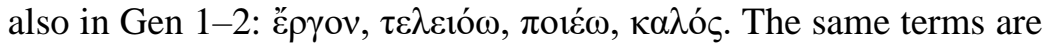
also used in the accounts of creation found in extra-biblical Jewish literature of the Second Temple period. ${ }^{32}$ Carlos Sosa Siliezar, having carried out a series of detailed comparative analyses, concludes by stating there are no direct applications of Gen 1-2 in the Johannine image of Jesus performing the works of the Father. On the other hand, however, he speaks of John's creative use of the

${ }^{29}$ The issue of the number of signs has also been discussed. As instances of the $\sigma \eta \mu \varepsilon i ̃ o v$, commentators indicated: the cleansing of the Temple $(2: 14-17)$, the sign of the vaó $\varsigma$ (2:18-22), Jesus' teaching about the serpent in the wilderness (3:14-15), the anointing of Jesus (12:1-8), the triumphal entry into Jerusalem (12:12-16), the maundy - "foot washing" (13:1-20), the Christophanies (20:1-29), and the miraculous catch of fish (21:1-14). See the chapter "Discussione sul numero dei segni” in G. Biguzzi, Il vangelo dei segni, Studi biblici 175, (Brescia 2014), 62-78. 30 From among the authors advocating for an actual reference between the Johannine number of seven signs to the seven days of creation, one must mention the following: D.A. Carson (1991), F.J. Moloney (2004), M. Rae (2008), J.K. Brown (2010), M. Coloe (2011), and A.M. Moore (2013). Bibliographical references to the works by the aforementioned scholars, alongside a convincing criticism of their thesis, were submitted by C.R. Sosa Siliezar, Creation, 130-41. For instance, A.M. Moore argues that in each of the seven signs above, also in the account of the miraculous catch of fish (21:1-14), there is a high percentage of vocabulary which should be understood as "creation indicators." Among these

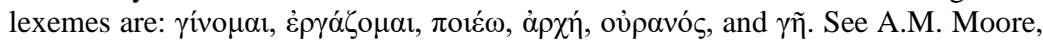
Signs of Salvation, 94-130. However, the meanings of these words are too general for them to be associated exclusively with the creation theme.

${ }^{31}$ See 4:34; 5:20.36; 7:3.21; 9:3-4; 10:25.32-33.37-38; 14:10-12; 15:24; 17:4.

${ }^{32}$ Numerous examples are provided by C.R. Sosa Siliezar, Creation, 78-82. 
terms, imagery, and notions drawn from Gen 1-2 in the account of Jesus' works of the Father. ${ }^{33}$ In applying the criterion of historical interpretation, one has to underscore the fact that already at the earliest stages of the interpretative traditions, the Johannine texts on the deeds of Jesus performing the works of the Father were seen as conveying references to the work of creation. For instance, Irenaeus (Adversus haereses 5.15.2) and John Chrysostom (Homiliae in

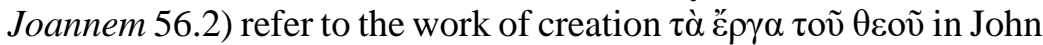
$9: 3$, understood as restoring the sight of the blind man. Tertullian (Adversus Marcionem 2.5) refers the works ( $\tau \grave{\alpha}$ है $\rho \gamma \alpha$ ) of Jesus in John 10:25 to the goodness of God the Creator. Athanasius (Orationes contra Arianos 2.15-16) refers John 5:17 to the Johannine Prologue, claiming that the Word of God performs the works of God the Creator. Ephrem the Syrian (Commentary on Tatian's Diatessaron 13.4) describes Jesus in John 5:17 as the Creator. All these connections, made already in antiquity, justify the search for references to the creation theme in the Johannine accounts of Jesus' signs. The most convincing attempts to identify such intertextual dependencies are found in relation to four particular narratives: the wedding feast at Cana (turning the water into wine), the healing of the paralytic, Jesus' walking on water, and the healing of the man born blind.

The first of these signs, Cana, with its abundance of wine, brings to mind the restoration of Israel, heralded and awaited throughout the Old Testament in the eschatological era (e.g., Amos 9:11-13). This restoration is conceived of as the restoration of the creation. The very transcendence of natural and physical laws, represented by the turning of water into wine, may be seen as an evocation of the image of God the Creator in Gen 1. ${ }^{34}$ The expression

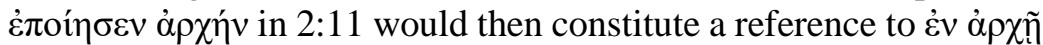

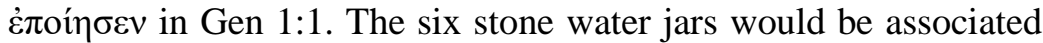
with the six days of God's work of creation (Gen 2:2 LXX). Water poured into these vessels, subsequently turned into wine, would

\footnotetext{
${ }^{33}$ C.R. Sosa Siliezar, Creation, 84. For more on the Johannine concept of works performed by the Father and Jesus see P.W. Ensor, Jesus and His "Works." The Johannine Sayings in Historical Perspective, WUNT II/85, (Tübingen 1996).

${ }^{34}$ So T.C. Voortman, Understanding, 152-3.
} 
signify the restored creation. ${ }^{35}$ Mary being addressed as a "woman" at Cana is to evoke the Eve of Gen 1-3. The fact that the Cana marriage occurred on the sixth day of the first week of Jesus' ministry would indicate the sixth day of the first week of creation, when the first pair of humans had been created. The marriage at Cana would in fact symbolise the marriage between God - the bridegroom, in the person of Jesus, the new Adam - and Church, the bride, in the person of Mary, the new Eve. Taken together, it serves as a foretoken of the renewal of the covenant and of the creation. ${ }^{36}$

Next, in the narrative of the healing of the paralytic, the theme of the Sabbath (5:9.10.16.18), as well as the expression "is still working" spoken about the Father $(5: 17)$, no doubt both refer to the Jewish debates about God's rest, as described in Gen 2:2-3. The earliest witnesses to these discussions are a text ascribed to Aristobulus of Alexandria (second century b.c.e.) preserved in one of the works by Eusebius of Caesarea (Praep. ev. 13.12.9-16), and also texts authored by Philo (Leg. All. 1.1-6; Cher. 87, 90). In the theological thought of the period, only God could work, judge, and give life on the day of the Sabbath. ${ }^{37}$ In the healing story, these three prerogatives are now likewise ascribed to Jesus, who operates much like the Father does (5:17.19-20). In fact, he performs the works of the Father $(5: 36)$. Jesus also serves as the judge $(5: 22.27 .29 .30)$. Lastly, he restores the dead to life $(5: 21)$, a fact tangibly indicated by his bringing an ill man back to full health. Of importance here is the semantics of the term vin's at 5:6.9.11.14.15, evoking notions of completeness, integrity, and wholeness. In the context of the theme of life, it is no accident that the dialogue further touches on the subjects of resurrection (5:21.25.29) and eternal life $(5: 24)$, as well as on the identity of Jesus, who is defined as life par excellence (5:26.40). Just as the works of God the Father are related

\footnotetext{
35 A. Serra, “Vi erano la sei giare...”. Gv 2,6 alla luce di antiche tradizioni giudaico-cristiane relatie ai "sei giorni" della creazione, w: Nato da Donna... (Gal 4,4). Ricerche bibliche su Maria di Nazaret (1989-1992), (Roma-Milano 1992), 141-88.

${ }^{36}$ A.M. Moore, Signs of Salvation, 135-9, argues that the mention of the third day in 2:1 should be understood as a reference to the resurrection and thus to the first day of the new creation.

${ }^{37}$ Gen 1-3; Deut 32:39; 1 Sam 2:6; 2 Kgs 5:7; Ezek 37:3-12; Hos 6:2; Wis 16:13.
} 
to all people, so the actions of Jesus are addressed to all $(5: 28)$. Indeed, the use of the imagery associated with creation helps to emphasise the divine identity of Jesus and his perfect unity with the Father (see 5:18-21). Further, it also demonstrates the effects of Jesus' salvific activity, which may be referred to as the new creation.

Many commentators see the image of Jesus "walking on the sea"

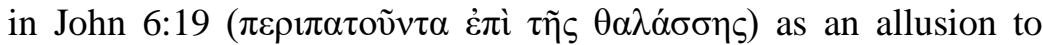
Job 9:8 LXX, which mentions God, "who alone stretched out the sky

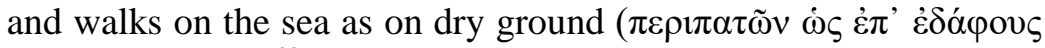
غ̇лì $\theta \alpha \lambda \alpha ́ \sigma \sigma \eta \varsigma) . " 38$ The argument for accepting the allusion is supported by the fact that the participle "walking/one who walks,"

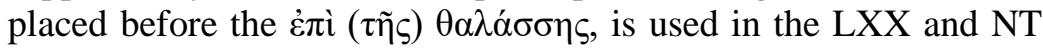
only in these two contexts - Job 9:8 and the descriptions of Jesus walking on water (Matt 14:25; Mark 6:48; John 6:19; Cf. Matt 14:26, and Mark 6:49). The image presented in Job 9:8 refers directly to the creation theme (cf. the context: Job 6:5-13). A similar association with the creation motif occurs in the Sibylline Oracles 6.9-17, where the "Son of the Immortal" (understood as Jesus), walking upon the waves, holds in his hand the whole world, earth, heaven, and the sea (see also Sib. Or. 8.272-274). The reference to the creation theme in John $6: 19$, through the allusion to Job 9:8, is aligned with the divine self-identification of Jesus as $\dot{\varepsilon} \gamma \omega \dot{~ \varepsilon i \mu u ~ i n ~}$ John 6:20. This evocation of the work of creation serves not only to underscore the divine identity of Jesus but also to harmonise with the subsequent literary context, where Jesus reveals himself to be the Lord sending the manna during the new Exodus. ${ }^{39}$

38 The first commentator to notice this intertextual reference may have been D.F. Strauss, The Life of Jesus Critically Examined, (London 1898), 504.

${ }^{39}$ Abraham Terian believes that the mention of the darkness ( $\left.\sigma \kappa о \tau i \alpha\right)$ that befell the disciples in the boat upon the sea (John 6:17) marks a reference to the darkness ( $\sigma \kappa \delta$ $\tau \circ \varsigma$ ) swept over the face of the waters in Gen 1:2. Patrick Madden adds the strong wind and the unruly sea, besides the darkness, as evoking the image of the primordial chaos of Gen 1:2. See A. Terian, Creation in Johannine Theology, in L. Miller, ed., Good News in History. Essays in Honor of Bo Reicke, (Atlanta 1993), 45-61; P.J. Madden, Jesus' Walking on the Sea. An Investigation of the Origin of the Narrative Account, BZAW 81, (Berlin 1997), 109. C.R. Sosa Siliezar (Creation, 111) associates the image of Jesus as God the Creator walking on water with the theme of "seeing," expressed by the verb $\theta \varepsilon \omega \rho \varepsilon \dot{\omega} \omega$. For the disciples beheld 
With the next focal passage, the account of the healing of the man blind from birth in John 9, the mention there of the devil, the murderer, and the liar "from the beginning" (8:44) directs us back to the serpent in Gen 3 (see Wis 2:23-24), preparing the reader for yet other allusions to Genesis creation accounts. Serving a similar function is the reference to Jesus' existence "before Abraham" (8:58), pointing to His pre-existence, and hence his life before the creation of the world. Then in both John 9:14.16 and in Gen 2:2-3 we find the theme of the Sabbath and, once again, how Jesus' activity on the Sabbath indicates his divine identity. John 9:3 sees

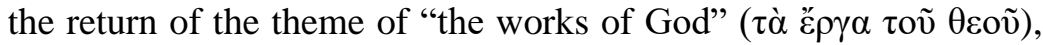
which in and of themselves constitute an allusion to the creative activity of God. Jesus being called "the light of the world" (9:5) refers back to the Prologue (1:4-5.9), where the Logos is identified with the light, and where the creation theme is of course heavily present. The making of mud ( $\pi \eta \lambda \hat{\prime} \varsigma)$ may be an allusion to Adam having been formed from the dust of the ground (Gen 2:7). ${ }^{40}$ The

( $\theta \varepsilon \omega \rho \varepsilon ́ \omega)$ Jesus walking on the sea (6:19). In Matt 14:26 and Mark 6:49, there is a mention of seeing (ópó $\omega$ ) a ghost. In the subsequent context in John, Jesus says that "everyone who beholds $(\theta \varepsilon \omega \rho \varepsilon ́ \omega)$ the Son and believes in him may have eternal life and I will raise him up on the last day" (6:40). Another place records the following words of Jesus: "the one who beholds $(\theta \varepsilon \omega \rho \varepsilon \dot{ } \omega)$ me beholds the one who sent me" (12:45). Ultimately, Jesus pleads with the Father for his disciples to behold $(\theta \varepsilon \omega \rho \varepsilon \dot{c} \omega)$ the glory that he had been given by the Father, stemming from the love between the Father and the Son preceding the very creation of the world (17:24).

${ }^{40}$ Christiane Koch suggests that both in the account of the creation of man in Gen 2:7 and in the healing of the man blind from birth in John 9:6 God's activity occurs in two stages: the preparation of the material (forming the man /preparing the mud) and its subsequent use (breathing in the nostrils / placing it upon the eyes). Furthermore, the Johannine verb غ̇ $\pi \imath \chi$ í $^{\circ}$ ("spread, smear on, anoint") could indicate the transference of the spirit to the blind man, as an allusion to the breath of life received by Adam from God. The fact that it was blindness "from birth" ( $\dot{\kappa} \kappa \gamma \varepsilon v \varepsilon \tau \tilde{\eta} \varsigma-9: 1$; see 9:2.19.20.32) was also to be an allusion to the creation theme, for the healing of the blind man ought to be regarded as an act of creation. See Ch. Koch, Geschaffen, um Gott zu sehen. Die Heilung des Blindgeborenen als "Schöpfungsereignis " in Joh 9,1-38, in A. Vonach, G. Fischer, eds., Horizonte biblischer Texte, OBO 196, (Göttingen 2003), 205-7. Barnabas Lindars sees in

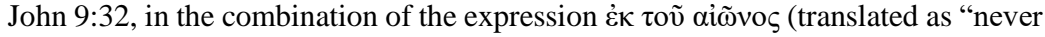
since the world began"), the opening of the eyes, and the mention of blindness from birth $(\gamma \varepsilon v v \alpha \dot{\alpha} \omega)$, "a hint" at the creation of light, the first act of creation (cf. Gen 1:3). 
term $\pi \eta \lambda$ ó $\varsigma$, which attracts the reader's attention due to its frequent occurrence $(9: 6.11 .14 .15)$, is used elsewhere in the context of the creation of the first man, in Job 10:9 and Isa 64:7. The text from the book of Job shares with John 9 the indication of the lack of sin (John 9:2-3; Job 10:7.14-15). The context of the passage from Isaiah introduces the people who had never seen with their eyes another god besides God and His works (oủ $\delta \dot{\varepsilon}$ oi ỏ $\varphi \theta \alpha \lambda \mu$ oì $\dot{\eta} \mu \tilde{\omega} v$

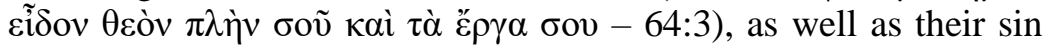
(64:4.5.6). ${ }^{41}$ I believe that also the recurring motif of $\sin$ (9:2-3.16.34.41) constitutes a reference to the creation theme. Jesus, accused of being a sinner (9:16.24.25), is essentially innocent. Here, he symbolises the new humanity; he is the new, sinless Adam. Indeed, to such a state - free from sin and a part of the new creation (understood as faith in Him) - Jesus also brings the man he healed, who had been accused of remaining in the state of sin from his birth (9:24, cf. 9:2). Being in sin from birth suggests the fallen state of creation, the consequence of the fall of Adam. After the fall, Adam regains his dignity within a sinless creation only thanks to the creative activity of Jesus, the new Adam. When it comes to identifying a creation allusion in the symbolic act of Jesus in John 9:6 (making and applying the mud), we can point to 1QS XI, 20-22, which speaks of people born of women, who are made of dirt and spittle, being pieces of formed clay. Similarly, according to 1QHa XX, 32-34, the man was created of clay and spittle. ${ }^{42}$ The interpretation of the healing of the blind man by reference to creation had already been put forth by ancient authors (e.g., Irenaeus, Haer. 5.15.2-4; 5.16.1; John Chrysostom, Hom. Jo. 56.2). Looking for the actual function served by the motif of creation in John 9, one may point to the issue of discovering the full identity of Jesus, a theme explored in the immediately preceding context (John 7-8). In John

B. Lindars, The Gospel of John, The New Century Bible Commentary, (Grand Rapids-London 1972), 349.

${ }^{41}$ For more on the associations with Isaiah, see J.D.M. Derrett, John 9:6 Read with Isaiah 6:10; 29:9, Evangelical Quarterly 66 (1994): 251-4; idem, Miracles, Pools, and Sight: John 9,1-41; Genesis 2,6-7; Isaiah 6,10; 30,20; 35,5-7, Bibbia e Oriente 36 (1994): 71-85.

${ }^{42}$ See D. Frayer-Griggs, Spittle, Clay, and Creation in John 9:6 and Some Dead Sea Scrolls, Journal of Biblical Literature 132 (2013): 659-70. 
9, Jesus is presented as possessing the prerogatives of God Himself, the Creator. Let us consider that, by performing "the works of God"

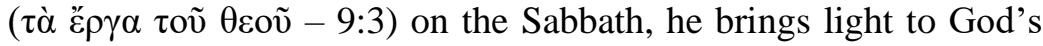
creation (cf. 1:9), represented here by the blind man. The man of darkness (i.e., of faithlessness), symbolised here by being blind, comes to the light of faith, symbolised by the newfound ability to see. The shift from the darkness (see "night" - 9:4) to the light (see "the light of the world" - 9:5) once again refers back to the creation theme introduced in the Prologue. The act of healing may, therefore, be seen as an act of the (new) creation, and Jesus described as God the Creator. In this context of the divine (creative) prerogatives of Jesus, including his work on the Sabbath (see John 5), it comes as no surprise that the subsequent section of the narrative presents Jesus as the judge of humanity (9:39-41), thus, again, possessing a quality reserved exclusively for God.

In summarising, the instances of allusions to the creation theme in the above four Johannine $\sigma \eta \mu \varepsilon i \alpha$, one will recognize that-as introduced in the Prologue - the motifs of life and light associated both with Jesus and creation return in John 5 (the notion of life), and in John 9 (light). Every man healed by Jesus is restored to the fullness and perfection experienced by the first man in the garden of Eden. With good reason, therefore, John Painter believes the expression "good works" ("ॄ $\rho \gamma \alpha \kappa \alpha \lambda \alpha$ ), denoting deeds originating with the Father and revealed through Jesus (John 10:32), to allude to the creative activity of God in Gen 1-2. In that sense, through the signs that He performs, Jesus reveals and continues the creative work of the Father, restoring the mankind and the earth to their ideal state. ${ }^{43}$ The last of the seven enumerated signs, the raising of Lazarus, is a direct harbinger of the resurrection of Jesus. It is worth recalling that in Judaism resurrection as such was always associated with the renewal of the creation. However, each of the preceding sings serves to foretell this greatest of signs, the $\sigma \eta \mu \varepsilon i \tilde{o} v$ par

43 J. Painter, Earth Made Whole. John's Rereading of Genesis, in J. Painter, R.A. Culpepper, F.F. Segovia, eds., Word, Theology, and Community in John, (St. Louis 2002), 65-84, especially 70, 77-8. 
excellence (2:18), which is the resurrection of Jesus, the first sign of the truly restored creation. ${ }^{44}$

\subsection{Other Allusions within the Book of Signs}

The idea of "being born from above (ő $v \omega \theta \varepsilon v)$ " (3:3.7), combined with the notion of being born of water and the Spirit (3:5) and that of being born of the Spirit (3:6.8), can all be seen as references to the motif of creation. ${ }^{45}$ According to Hans U. Weidmann, the message conveyed in John 3:31 (defining the man coming from above - óv $\omega \theta \varepsilon v)$ refers to the account of the creation of man, in whose nostrils God had breathed the breath of life (Gen 2:27). ${ }^{46}$ Terence C. Voortman is of the opinion that the image of Jesus healing the son of the official using his word (4:50) evokes the image of God creating the world with his word. ${ }^{47}$ Ruben Zimmermann claims that the motif of the "gate" in John 10:1.2.7.9 may allude to the gates of paradise, expected to be opened by the Messiah (Testament of Levi 18.10-11; cf. 4 Ezra 8.52). ${ }^{48}$

To make the picture complete, it is worth also mentioning some of the less plausible proposals of intertextual references. Paul $\mathrm{S}$. Minear suggested that the description of Jesus as the Lamb of God, who takes away the sin of the world (1:29) is "surely an echo" of the narrative in Gen 3, and thus an evocation of the removal of the sin committed by Adam and Eve, which stained all of humanity, i.e., the world. ${ }^{49}$ The author also regards the mention of a pasture

\footnotetext{
${ }^{44}$ See J. Painter, Earth, 77: "the signs of Jesus are miracles, new acts of creation." ${ }^{45}$ B. Witherington, New Creation or New Birth? Conversation in the Johannine and Pauline Literature, in Conversation in the Wesleyan Tradition, in K.J. Collins, J.H. Tyson, eds., (Nashville 2001), 121-2.

${ }^{46}$ H.U. Weidmann, The Victory of Protology Over Eschatology? Creation in the Gospel of John, in T. Nicklas, K. Zamfir, eds., Theologies of Creation in Early Judaism and Ancient Christianity, DCLS 6, (Berlin 2010), 299-334.

47 T.C. Voortman, Understanding, 84-7.

${ }^{48}$ R. Zimmermann, Symbolic Communication between John and His Reader. Garden Symbolism in John 19-20, in T. Thatcher, S.D. Moore, eds., Anatomies of Narrative Criticism. The Past, Present, and Futures of the Fourth Gospel as Literature, SBLRBS 55, (Atlanta 2008), 234.

${ }^{49}$ P.S. Minear, Christians and the New Creation, 85.
} 
(John 10:9) as an allusion to the fertile land in Gen $1 .{ }^{50}$ Ruben Zimmermann sees the mention of the serpent lifted up in the desert (John 3:14) as associated with the serpent in Gen 3:1-8.10. However, the Edenic serpent was promising knowledge, and unable to fulfill his promise, whereas Jesus, "the elevated serpent," truly does bring wisdom (John 17:7-8). Indeed, the narrative of Gen 3 does speak of the promise of both knowledge and deathlessness ("You will not die!" - 3:4), and the people in paradise did acquire the knowledge of good and evil, as promised by the serpent (see 3:22). But deprived of the tree of life they could no longer hope for immortality. The same German exegete believes the mysterious food that Jesus mentions in John 4:32-34 to have been a reference to the food prepared by angels for Adam in paradise (see Life of Adam and Eve 4; b. Sanh. 59b). ${ }^{51}$ However, this suggestion likewise proves difficult to embrace in light of 4:34 (where it is doing the Father's will which constitutes Jesus' food). Ruben Zimmermann also sees the Johannine image of the bread that came from heavennot like the bread eaten by the ancestors of Jesus' listeners, who had died (John 6:58) — as a reference to Gen 3:19, which introduces the notion of acquiring bread through sweat until the death. ${ }^{52}$ That association, too, seems implausible, since Jesus is speaking about the manna eaten by the Israelites during their travels in the desert, while the text in Gen speaks of the necessity of work in order to acquire food throughout one's earthly life.

Several other proposed connections at least bear mentioning. William J. Phythian-Adams suggested that the theme of water, found in John 4:13-14 and 7:37-39, is an "allusion to the waters of the abyss, stored at the Creation beneath the 'navel' ('belly') of the earth." ${ }^{53}$ Aileen Guilding claimed that the image of eating and death in Gen 3 is an allusion to the imagery of eating and life in John 6:50-51.$^{54}$ Abraham Terian believes that the light ( $\left.\varphi \tilde{\omega} \varsigma\right)$ in John 11:9

50 Ibid., 95.

${ }^{51}$ R. Zimmermann, Symbolic Communication, 234.

52 Ibid., 233.

53 W.J. Phythian-Adams, The New Creation in St. John, Church Quarterly Review 144 (1947): 69.

${ }^{54}$ A. Guilding, The Fourth Gospel and Jewish Worship: A Study of the Relation of St. John's Gospel to the Ancient Jewish Lectionary System, (Oxford 1960), 61-3. 
and 12:35 is meant to evoke the creation of the lightness $(\varphi \tilde{\omega} \varsigma)$ in Gen 1:3-5. ${ }^{55}$ Thomas Brodie considers the fact of the Father and the Son (ultimately also with the Spirit of the Paraclete) making their home in the faithful (14:23) to be an indication of the notion of the image of God in Gen 1:26. ${ }^{56}$ Finally, according to Craig Keener, the idea of the image of God in Gen 1:26 was also to constitute the backdrop of the account of the healing of the paralytic in John $5 .^{57}$

\section{The Book of Glory}

Jesus' prayer in John 17 features two marked references to the idea of the world's creation: "before the world was" ( $\pi \rho$ ò $\tau$ oṽ $\tau$ òv

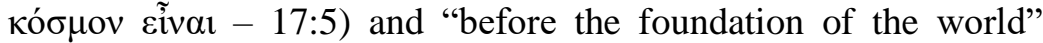

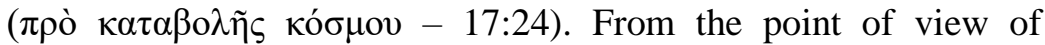
congruence of contexts, the suggested allusion to Prov 8:23-25 and Wis 7:25 is rather unconvincing. ${ }^{58}$ We note that the two evocations of the creation of the world are situated at the beginning and at the end of Jesus' prayer, setting up a thematic inclusio. Both allusions serve to connect the past with the present and the future. Here, the glory that Jesus had had before the world was created would be heralded by the Father, in order for it to be seen by the disciples of Jesus. Both allusions underscore the truth of Jesus' existence, no longer the enigmatic o $\lambda$ ó $\gamma$ o $\varsigma$ of the Prologue - he is there alongside the Father already before the making of the world. In John 17:5.24, however, as opposed to the Prologue, Jesus is not described as actively involved in the work of creation. Just as in John 1:10 the world was created through o $\lambda$ ó $\gamma \circ \varsigma$ and the world did not recognise ó $\lambda$ ó ${ }^{\circ}$, so too in 17:24 the world did not recognise the Father, even though (as the text implicitly suggests) this world had been created by the Father. According to C.R. Sosa Siliezar, the sense of the allusion to Gen 1 in John 17:5.24 is perfectly aligned with the global purpose of all the Johannine references to the creation,

\footnotetext{
55 A. Terian, Creation, 45-61.

56 T.L. Brodie, The Gospel according to John. A Literary and Theological Commentary, (New York 1993), 467.

57 C.S. Keener, The Gospel of John. A Commentary, (Peabody 2003), 649.

${ }^{58}$ See the detailed comparative analyses in C.R. Sosa Siliezar, Creation, 56-7.
} 
i.e., emphasising the very close relationship between the Father and Jesus. ${ }^{59}$ The idea of creation presented in the Prologue, voiced by the narrator at the outset of the Johannine narrative, is then explicitly recalled towards its end, directly before the passion and death of Jesus, in the words of Jesus himself.

The allusions to Gen 1-2 in the Johannine account of the passion and resurrection of Jesus are numerous and have been the subject of many analyses. We will first discuss the linkage that seems the most obvious among them, involving the breathing of the Holy Spirit on his disciples. Later we will go on to talk about the less evident ones, and ultimately to the proposed intertextual references we find entirely implausible.

The connection between the breath of the resurrected Jesus (John 20:22) and the image of God the Creator breathing life into the nostrils of the man formed from the dust of the earth (Gen 2:7) does not raise any major doubts. Just like God breathed ( $\dot{\varepsilon} \mu \varphi v \sigma \alpha ́ \omega)$ into Adam the breath of life ( $\pi v \circ \eta \eta v \zeta \omega \tilde{\eta} s)$, so Jesus is breathing $(\dot{\varepsilon} \mu \varphi v \sigma \alpha ́ \omega)$ on his disciples, giving them the Holy Spirit ( $\pi v \varepsilon \tilde{v} \mu \alpha$ ä $\gamma 10 v)$. It is worth pointing out that both passages have the same

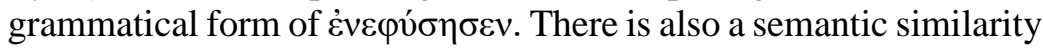
between $\pi v o \eta$ and $\pi v \varepsilon \tilde{v} \mu \alpha$, referring to the notion of wind. The

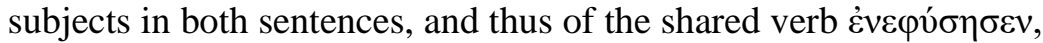
is God: ó $\theta \varepsilon o ́ \varsigma$ (Gen 2:7) and ó 'Inбoṽ (John 20:19.21). On both occasions, the breath constitutes a single, discreet event. The belief that God breathed his spirit into the man in the act of creation was, once again, demonstrably present in the Judaism of the period when the New Testament was composed. According to Wisdom of Solomon 15:11, God breathed into Adam a living spirit

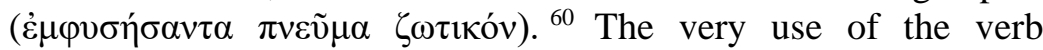
$\dot{\varepsilon} \mu \varphi v \sigma \alpha ́ \omega$ also introduces connotations associated with transferring life, since in $3 \mathrm{Kgdms}$ 17:21 LXX Elijah breathed ( $\dot{\varepsilon} \mu \varphi v \sigma \alpha ́ \omega)$ on a lad restoring him to life. Further, in Ezek 37:9 LXX Ezekiel

\footnotetext{
59 Ibid., 64.

${ }^{60}$ The idea of transferring spirit through the act of breathing in Gen 2:7 can be found

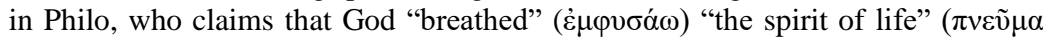
$\zeta \omega \tilde{\eta} \varsigma)$ (Det. Pot. Ins. 80; Leg. All. 3.161). According to Philo, the man created by God is a "spirit of God" ( $\pi v \varepsilon \tilde{u} \mu \alpha \theta$ cíov), for he received "the divine spirit" ( $\pi v \varepsilon \tilde{v} \mu \alpha$

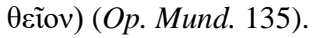


on God's order commands the Holy Spirit to breathe ( $\dot{\varepsilon} \mu \varphi v \sigma \alpha ́ \omega)$ into the slain, that they may live. In the New Testament, the verb $\dot{\varepsilon} \mu \varphi v \sigma \alpha ́ \omega$ appears only once, in John 20:22, a compelling hint for us to interpret the scene of transferring the Holy Spirit in the context of the renewal of creation. The association between the breath in John 20:22 and that in Gen 2:7 can also be found in the writings of the Church Fathers, yet another argument (meeting a preliminary criterion) for the actual existence of the allusion. ${ }^{61}$ When exploring the meaning of this allusion for the interpretation of John 20, one has to bear in mind that the reader automatically recognises the divine identity of the Risen One, whose relationship with the Father is identical to that of the Logos in the Prologue $(1: 1-2),{ }^{62}$ since only God has the prerogative of granting the Spirit. ${ }^{63}$ By performing an act indicative of the activity of God the Creator in Gen 2:7, Jesus at the same time points to the entire world as the addressees of his salvific mission. Hence the universal scope of the mission of Jesus' disciples, sent into the world with the power to remit and retain sins. ${ }^{64}$ Some authors define this moment in the Gospel of John as its climax. Furthermore, it is not insignificant that the breath of the Risen Christ is situated at the centre of the three accounts of Christophany in John $20 .^{65}$

61 Theodore of Mopsuestia, Comm. Jo. 7.20-22; Cyril of Jerusalem, Myst. Cat. 17.12; Cyril of Alexandria, Comm. Jo. 12.

${ }^{62}$ See M.M. Thompson, The Breath of Life. John 20:22-23 Once More, in G.N. Stanton, B.W. Longenecker, S.C. Barton, eds., The Holy Spirit and Christian Origins, (Grand Rapids 2004), 71 and 77.

${ }^{63}$ C.S. Keener, John, 1205. The author cites many texts in the Old Testament corroborating the thesis.

${ }^{64}$ This aspect is discussed at length by C.R. Sosa Siliezar, Creation, 169-72.

65 E.M. Humphrey, New Creation, in K.J. Vanhoozer, ed., Dictionary for Theological Interpretation of the Bible, (Grand Rapids 2005), 536: "The climax of the Fourth Gospel presents Jesus as 'breathing' upon the apostles after the pattern of the creating God who breathed upon the Edenic couple; now they receive the Spirit, and not simply the gift of life." C.R. Sosa Siliezar, Creation, 161: "this instance of creation imagery occupies a strategic place in John." The connection between John 20:22 and the targumic reading of Gen 2:7 is exhaustively discussed by M. Wojciechowski, Le don de L'Esprit Saint dans Jean 20.22 selon Tg. Gn. 2.7, New Testament Studies 33 (1987): 289-91; T.R. Hatina, John 20:22 in Its Eschatological Context: Promise or Fulfilment?, Biblica 74 (1993): 196-219. 
Another generally accepted allusion to Gen 1-3 in the Johannine account of the passion and resurrection of Jesus is the motif of the garden. We note that the arrest of Jesus, as well as his crucifixion

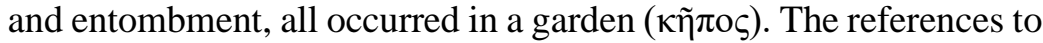
a garden in 18:1 and 19:41 set up an inclusio of the entire narrative of the passion and death of Jesus, evoking the image of the garden of Eden. Even though the term $\kappa \tilde{\eta} \pi \mathrm{s}$ does not appear in Gen 2-3 in the LXX translation (instead, there are thirteen instances of $\pi \alpha \rho \alpha ́ \delta \varepsilon 1 \sigma o \varsigma$ ), we do encounter it in the translations by Aquila (Gen $2: 8,3: 2)$, and by Theodotion (3:2). What matters, however, is not a direct terminological parallel, but the identity of ideas. Additionally, when searching for verbal analogies, one should acknowledge the fact that the noun $\kappa \tilde{\eta} \pi \circ \varsigma$ is used as the synonym of $\pi \alpha \rho \alpha ́ \delta \varepsilon 1 \sigma o \varsigma$ in Eccl 2:5, and Sir 24:30-31. Furthermore, in Ezek 36:35 LXX the garden of Eden is referred to as $\kappa \tilde{\eta} \pi \mathrm{s}$, and similarly in the translations by Aquila and Theodotion of Isa 51:3, Ezek 28:13, and 31:8. ${ }^{66}$ It is possible that John refrains from using the word $\pi \alpha \rho \alpha \delta \delta \varepsilon 1 \sigma o \varsigma$, because that term is applied in the New Testament to refer to the celestial (supernatural) reality of paradise (see Luke 23:43; 2 Cor 12:4; Rev 2:7). The presence of an allusion to Eden in the Johannine use of $\kappa \tilde{\eta} \pi \mathrm{o} \zeta$ is further attested to by the recurrence of that linkage in patristic exegeses (e.g., Cyril of Jerusalem, Myst. Cat. 13.19; Cyril of Alexandria, Comm. Jo. 11-12). ${ }^{67}$ The Johannine reference to the garden of Eden in the

\footnotetext{
66 Josephus Flavius also describes the Garden of Eden as $\kappa \tilde{\eta} \pi \circ \varsigma_{\text {in }}$ Ant. 1,38.45.51. ${ }^{67}$ For more on this topic, see F. Manns, Le symbolisme du jardin dans le récit de la passion selon St Jean, Liber Annuus 37 (1987): 53-80; R. Zimmermann, Symbolic Communication, 221-35. Mariusz Rosik thinks that the mention of an "early morning, when it was yet dark" in John 20:1 refers to Eden's location "in the east" (Gen 2:8). Moreover, "in the east" would mean "where the sun rises" and in this sense it would symbolise the awakening of life. In his own words: "The day's life begins with the coming of the sun from the east, the first people were called to life by God in Eden in the east; and, finally, at sunrise Mary Magdalene discovered Jesus' empty tomb, the sign of his new life." M. Rosik, Discovering the Secrets of God's Gardens. Resurrection as New Creation (Gen 2:4b-3:24; Jn 20:1-18), Liber Annuus 58 (2008): 86. A critical evaluation of this intertextual association between the Johannine $\kappa \tilde{\eta} \pi \circ \varsigma$ and Gen 2-3 was presented by C.R. Sosa Siliezar, Creation, 179-90. In his view, the only admissible intertextual reference of the Johannine
} 
context of the passion and resurrection of Jesus would thus demonstrate the restored availability of paradise for the humanity redeemed by Jesus. Hence, the Fourth Gospel (John 18-20) ends in the exact same manner as the Revelation of John (Rev 21-22), namely with the reference to the garden of Eden.

Less obvious, but well worth our attention, are the following proposed allusions to Gen $1-3$ in the Johannine account of the passion and resurrection of Jesus (John 18-20). Edwin C. Hoskyns suggested that the image of Jesus bowing his head on the cross

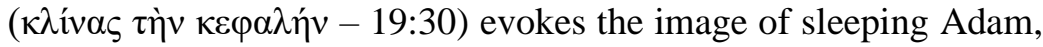
from whose rib Eve is being created (Gen 2:21-22). Just like in Gen 1:2 the Spirit of God is the instrument of creation, so the Spirit transferred on the cross, at the moment of Jesus' death, is the instrument of the renewed creation. The mother of Jesus standing by the cross ought to be recognised as Eve, the wife of Adam. The fact that Jesus addresses Mary with the word "woman" ( $\gamma v v \eta$ ) would thus refer to the texts involving Eve in Gen 2:23 and 3:20. ${ }^{68}$ The identification of Mary as the new Eve was already known in antiquity. ${ }^{69}$ At the same time, Mary, the new Eve, together with the anonymous beloved disciple, constitute the actual bride of God, the new Eve, i.e., the church. Of no small significance is the fact that the crucifixion occurred on Friday, the sixth day of the week, pointing to the sixth day of the first week of creation, when Adam and Eve were created (Gen 1:24-31). Mary and the beloved disciple, constituting the church, become the new humanity, or the renewed humanity.

For my part, I would like to direct the reader's attention to rabbinic texts speaking of Adam's sin, which was to have taken place on the sixth day at ten o'clock. ${ }^{70}$ The calling of the first two of Jesus' apostles, including one unknown by name and thus possibly

$\kappa \tilde{\eta} \pi \mathrm{o} \varsigma$ is the Old Testament notion of the royal garden (see $2 \mathrm{Kgs} 25: 4$; Esth 7:7-8; Eccl 2:5; Jer 52:7). However, it is worth underscoring that Josephus Flavius, when describing the royal garden, uses both $\kappa \tilde{\eta} \pi \circ \varsigma$ (Ant. 9.227; 11.265), and $\pi \alpha \rho \alpha ́ \delta \varepsilon 1 \sigma o \varsigma$ (Ant. 10.46).

${ }^{68}$ E.C. Hoskyns, Genesis, 211.

${ }^{69}$ This was posited already by Justin Martyr (Dial. 100), who died before A.D. 167, although in the context of Luke 1:35.

${ }^{70}$ See Pesiq. Rab. 46.2; Pesiq. Rab Kah. 23.1; Midr. Ps. 92 §3; Lev. Rab. 29.1. 
the anonymous beloved disciple in 19:26, occurred precisely at ten o'clock (1:39). Hence, we may speak of the reversal of the situation from the garden of Eden through the work of Jesus. The new Adam and Eve, restored to the paradisiac state, are the community of the church. In line with that interpretation, Mary Magdalene, addressed by Jesus as "woman" (20:15), is also the figure of the new Eve and of the church community. Jesus calling Mary by her name (20:16) may also be a reference to Adam naming the first woman Eve (Gen $3: 20) .{ }^{71}$ In contrast to the first Eve's disobedience to God's precept, the new Eve, symbolised here by Mary Magdalene is obedient to Jesus' precept, bringing the tidings of his resurrection to his brothers. $^{72}$

Some exegetes see a reference to the completion of the work of God in the words uttered by Jesus on the cross: "Jesus, realising that everything was completed ( $\tau \varepsilon \tau \varepsilon \dot{\lambda} \varepsilon \sigma \tau \alpha \mathrm{l})(19: 28)$. . . , said: «It is completed ( $\tau \varepsilon \tau \varepsilon \dot{ } \varepsilon \varepsilon \sigma \tau \alpha 1) » "$ (19:30). The idea of completing ( $\tau \varepsilon \lambda \varepsilon \dot{\varepsilon} \omega)$, as presented here, is associated by commentators with the idea of

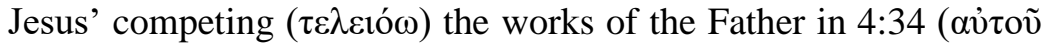

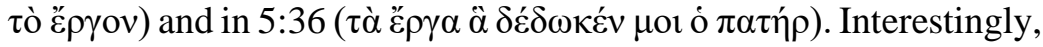
in the account of creation in Gen 1-2, the term $\tau \hat{\alpha}$ है $\rho \gamma \alpha$ also appears, in the phrase that God "left off on the seventh day from all his works

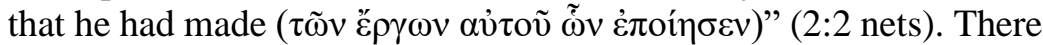
is also a verb derived from the Johannine $\tau \varepsilon \lambda \varepsilon \dot{\varepsilon} \omega$, expressing the idea of something being brought to an end, complete, $\sigma v v \tau \varepsilon \lambda \varepsilon \dot{\varepsilon} \omega$, used in the sentence: "the heaven and the earth were finished ( $\sigma v v \varepsilon \tau \varepsilon \lambda \varepsilon \dot{\sigma} \sigma \eta \sigma \alpha v)$ " (Gen 2:1 nets). Additionally, it should be noted that in John 19:31, directly following the citation of Jesus' final word on the cross, there is a double mention of the Sabbath ( $\dot{\varepsilon} \nu \tau \tilde{\omega}$

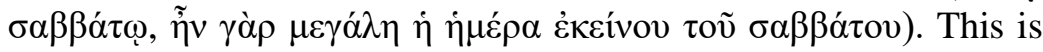
supposed to be a reference to the seventh day of creation, the Sabbath of God, in Gen 2:2-3. The actual existence of an intertextual link between John 19:28-31 and Gen 1-2 may be corroborated by

${ }^{71}$ See A. Reinhartz, To Love the Lord. An Intertextual Reading of John 20, in F.C. Black, R. Boer, E. Runions, eds., The Labour of Reading. Desire, Alienation, and Biblical Interpretation, SBL Semeia Studies 36, (Atlanta 1999), 63.

${ }^{72}$ M.L. Coloe, Theological Reflections on Creation in the Gospel of John, Pacifica 24 (2011): 8: "The woman in the garden of John 20 reverses the actions and consequences of the woman in the garden of Genesis." 
the incompleteness of the creation as described in Gen 1-2 from its very beginning, that is, already before the sin of man. Thus, the fullness of creation, or the completion of the work of creation, only occurs through the acts of Jesus, his rest during the Sabbath, and his rising from the dead on the first day of the new week of the completed creation. ${ }^{73}$

In the Johannine chronology, Jesus dies on Friday and remains in his tomb on the Sabbath, the final day of the week. Jesus' resurrection takes place on the first day of the following week. This is not an accidental piece of information, as it is provided twice:

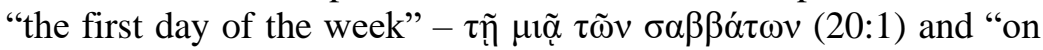

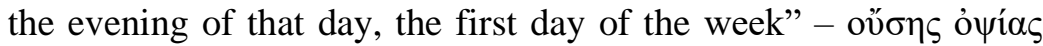

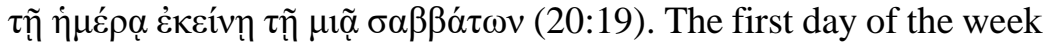
is mentioned in the narrative yet once more, when the Evangelist speaks of another Christophany which, occurred "after eight days"

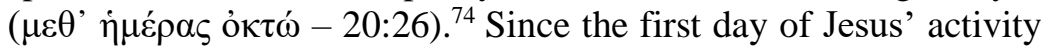
recalls the first week of creation, also the final week of his life may

${ }^{73}$ M. Hengel, The Old Testament in the Fourth Gospel, Horizons in Biblical Theology 12 (1990): 33-4; J.K. Brown, Creation's Renewal, 285-6. On the topic of completion of creation by Jesus and his disciples (the church) see also: R.T. Stamm, Creation and Revelation in the Gospel of John, in J.M. Myers, ed., Search the Scripture: New Testament Studies in Honor of Raymond T. Stamm, (Leiden 1969), 13-32; S.M. Mc Donough, Christ as Creator. Origins of a New Testament Doctrine, (Oxford 2009), 213-34. Of course, the reference to the completion of Jesus' work is not the only interpretation of John 19:28-30. The text also speaks of the fulfillment of the Scriptures. For an extensive treatment of the issue, see R. Vignolo, La morte di Gesù nel Quarto Vangelo come compimento, in G. Ghiberti, ed., Opera Giovannea, Logos. Corso di studi biblici 7, (Torino 2003), 273-92, (The author speaks of four different instances of completion here: of Jesus' mission, of the Scriptures, of Jesus' love [see 13:1], and of Jesus' desire); C. Mariano, Tetelestai. Il significato della morte di Gesù alla luce del compimento della Scrittura in Gv 19,16b-37, Quaderni della rivista di scienze religiose 14, (Roma 2010). However, it would be incorrect to limit the interpretation of John 19:28-30 solely to the fulfilment of the Scriptures.

${ }^{74}$ The understanding of the eighth day as "the beginning of another world" (ö $\lambda \lambda$ ov

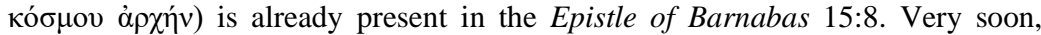
Christians came to identify the eight day with the day of the resurrection and of the new creation. For instance, Justin Martyr (Dial. 41.4) interprets the circumcision, in the Jewish tradition occurring on the eighth day, as a type of the true circumcision which occurred on the eighth day and involved the removal of error and evil by virtue of Jesus' resurrection. 
refer to the first week of creation in Gen 1. Just as God rested after completing his work of creation on the seventh day (Gen 2:2-3), so too Jesus rests on the Sabbath in his tomb, having performed the work entrusted to him by the Father. The resurrection, then, on the first day of the new week, may thus indicate the new creation. ${ }^{75}$

The two angels in the tomb of Jesus (20:12) may allude to the two cherubim guarding the gate to the garden of Eden (Gen 3:24). ${ }^{76}$

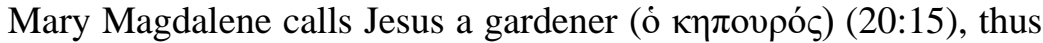
evoking the image of God as the one who planted the garden of Eden (Gen 2:8), and also Adam, placed in Paradise with the task of performing the duties of a gardener (Gen 2:15) ${ }^{77}$ In a reference to the ancient Near Eastern notion of a king as a gardener (for instance, "the gardener" was an official title of the rulers of Mesopotamia), Jesus could be seen as the king in his garden of new creation, much like Adam was the royal gardener in Eden. ${ }^{78}$ The allusion to the garden of Eden in John 20:15 was noticed already by Jerome (Hom. 87).

The sin of the first men brought into the world the fear of divinity (Gen 3:10). Mary Magdalene's lack of apprehension over the angels in John 20:11-14 is surprising, considering the synoptic narratives

75 On the role of the Johannine Sabbath interpreted in light of the creation, see A.J. Droge, Sabbath Work / Sabbath Rest: Genesis, Thomas, John, History of Religions 47 (2007-2008): 112-41.

${ }^{76}$ For instance, J.N. Suggit, Jesus the Gardener. The Atonement in the Fourth Gospel as Re-creation, Neotestamentica 33 (1999): 167; M. Rosik, Discovering the Secrets, 91-3.

${ }^{77}$ N. Wyatt, 'Supposing Him to Be the Gardener' (John 20,15). A Study of the Paradise Motif in John, ZNW 81 (1990): 21-38. C. R. Sosa Siliezar, Creation, 174-9, denies the above connection, pointing out that in the Second-Temple Jewish texts neither God nor Adam was referred to as a gardener. However, it is true that

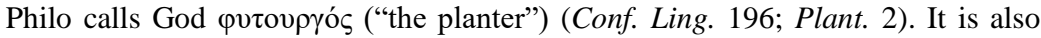
obvious that the biblical image of God planting the garden of Eden was commonly known (cf. 4Q504 8.6; Josephus Flavius, Ant. 1.37; 4 Ezra 3.5-6; 1 Enoch 25.4-7; 2 Baruch 4.3).

${ }^{78}$ In this vein, J. Schaper, The Messiah in the Garden. John 19:38-41, (Royal) Gardens, and Messianic Concepts, in M. Bockmuehl, G.G. Stroumsa, eds., Paradise in Antiquity. Jewish and Christian Views, (Cambridge 2010), 17-27; A. Kubiś, The Book of Zechariah, 464-5. As to the ANE background see G. Widengren, The King and the Tree of Life in Ancient Eastern Religion (King and Saviour IV), UUA 1951/4, (Uppsala-Leipzig 1951). 
speaking of women being afraid of the angelophany (see Matt 28:4-6; Mark 16:5-6; Luke 24:5). The fear of God, which appears for the first time in the garden of Eden, disappears in the new Eden, that is the garden of Jesus the Messiah, owing to the blotting out of sins by Jesus, identified as the mercy seat (i $\lambda \alpha \sigma \tau \eta ́ p i o v$, cf. Rom 3:25). ${ }^{79}$

Jesus seems to be recognised as the tree of the knowledge of good and evil, and the tree of life. The prohibition of touching the tree of good and evil (Gen 3:3) appears to have been lifted, for Mary Magdalene does touch Jesus ${ }^{80}$, and Thomas will be encouraged to do so later (20:27). Just as trees were created on the third day (Gen $1: 11-12)$, including the tree of life and the tree of the knowledge of good and evil, so too on the third day (2:19-20) Jesus reveals himself to be the true tree of life, which everyone has access to. According to 1 Enoch $25: 4$, touching the tree of life will only occur during the great judgement, when the tree is made available to the just and pious, and its fruits are made accessible to the chosen (cf. 3 Enoch 23:28; Testament of Levi 18:10-11). Meanwhile, the tree itself will be transferred to the temple of God. In light of Jubilees 3:10-13, the touching of the tree is prohibited, for it is identified as sanctity and sanctuary. The above correspondences all fit perfectly with what we know of Johannine theology. ${ }^{81}$

\footnotetext{
${ }^{79}$ For more on the subject, see A. Kubiś, Znaczenie pozycji aniołów w grobie Jezusa w J 20,12, The Biblical Annals 6 (2016): 482-5.

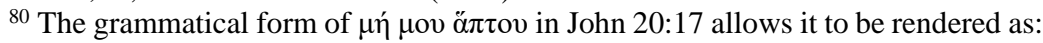
"Stop touching me."

${ }^{81}$ For more on the subject, see A. Kubiś, Zechariah 6:12-13 as the Referent of $\gamma \rho \alpha \varphi \dot{\eta}$ in John 2:22 and 20:9. A Contribution to Johannine Temple-Christology, The Biblical Annals 2 (2012): 177-81; idem, Znaczenie, 484-5. The potential connection between Jesus' prohibition of touching him and Adam prohibiting Eve from touching him (Apocalypse of Moses 31:3-4) is discussed by M.R. D'Angelo, A Critical Note: John 20:17 and Apocalypse of Moses 31, Journal of Theological Studies 41 (1990): 532-3. Adele Reinhartz, To Love the Lord, 63, sees Jesus' prohibiting Mary Magdalene from touching him as the reversal of the situation described in Gen 2:24. The relationship between man and woman is directed at being together, becoming "one flesh." However, the relationship with Jesus transcends any such categories. Alison Jasper believes Jesus' prohibition of touching to have been a reference to the brutal expulsion of the first humans from Eden. In both cases, the act of rejection occurs following a display of inadequate
} 
Among the less convincing intertextual connections between Gen 1-3 and the Johannine "Book of Glory," one may list the following suggestions put forth by various exegetes: Edwin C. Hoskyns suggested that there is an allusion to Gen 2:23 in John 16:21. Just as a nameless woman ( $\gamma v v \eta)$ in John 16:21 is burdened by suffering, so too in Gen 3:16 a nameless woman ( $\gamma v v \eta ́)$, later identified as Eve (3:20), is burdened by suffering. According to some exegetes, Pilate's "Behold the Man!" exclamation (19:5) refers on a deeper level (via the phenomenon of double entendre) to the Adamic typology, presenting Jesus as the anti-type of the Edenic Adam. ${ }^{82}$ According to M.L. Coloe, the description of the location where Jesus was crucified, between ( $\mu \varepsilon \dot{\sigma o v}$ ) two other persons (John 19:18) echoes the fact that God planted the tree of life in the middle ( $\dot{\varepsilon} \vee \mu \varepsilon \dot{\varepsilon} \sigma \omega)$ of the garden (Gen 2:9). ${ }^{83}$ Yves Simoens sees the mention of the darkness in John 20:1 as a reference to the first day of creation, underscoring the presence of the idea of separating the darkness from the light, as one of the motifs typical of John. ${ }^{84}$

There are also an abundance of entirely implausible proposals seeking to link the Book of Glory to Gen 1-3. Raymond T. Stamm suggested that the command to be fruitful and to multiply, in order to fill the earth (Gen 1:28), as well as the mandate to cultivate and keep the garden of Eden (Gen 2:15), both continue to be binding and are reflected in Jesus' claim that: "The one who remains in me, and I in him, he bears much fruit" (John 15:5). ${ }^{85}$ Another claimed conceptual parallel concerns the intimacy between the Creator and the man in the garden of Eden, such that God was strolling and ready to meet and talk to Adam, a scenario linked to the image of restored closeness between Creator and man represented by Jesus' beloved

knowledge. A. Jasper, Interpretative Approaches to John 20,1-18. Mary at the Tomb of Jesus, Studia Theologica 47 (1993): 107-17.

${ }^{82}$ M.D. Litwa, Behold Adam. A Reading of John 19:5, Horizons in Biblical Theology 32 (2010): 129-43; J.K. Brown, Creation's Renewal, 281. See also A. Kubiś, The Old Testament Background of "Ecce Homo" in John 19:5, Biblica et Patristica Thorunensia 11/4 (2018): 507-509.

${ }^{83}$ C.M. Coloe, Creation, 5.

84 Y. Simoens, Selon Jean, Collection IET 17, (Bruxelles 1997), vol. 3, 867.

${ }^{85}$ R.T. Stamm, Creation, 14. 
disciple leaning on his bosom (John 13:23). ${ }^{86}$ We discern another improbable allusion in the encounter between Jesus and Judas

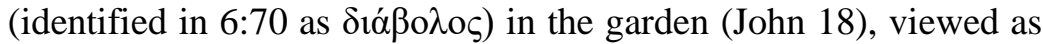
evoking Adam's battle with the serpent in Gen 2-3. ${ }^{87}$ There are multiple problems here: First, Adam does not fight the serpent in Gen 2-3, neither does Jesus fight Judas in John 18:3; moreover, the scene of Jesus' capture does not have to be set in a garden, as the verb used in John 18:4 is $\dot{\varepsilon} \xi \dot{\varepsilon} \rho \chi 0 \mu \alpha u .{ }^{88}$ Then Frédéric Manns offers some questionable connections related to John's Gethsemane narrative: He believes the absence of Jesus' agony there (18:1-12) harks back to the biblical concept of "the garden of delight" (Gen 3:23.24; Joel 2:3; Ezek 28:13; 31:9; 36:35). The concept of "Adam's glory," widely attested in intertestamental literature, ought to be associated with Jesus' glory revealed in the garden, during his arrest.

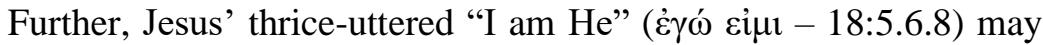
point to the presence of God's Shekhinah, which was also believed to have resided in the garden of Eden. ${ }^{89}$

More tenuous linkages worth at least brief mention: With some

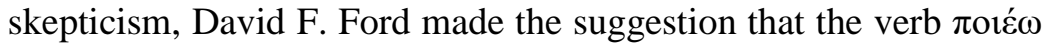
in John 20:30 and 21:25 evokes Gen 1:1. ${ }^{90}$ J.N. Sanders and B.A. Mastin claim that the vocative kúpı in John 20:15, maygiven its ambiguity - refer to Jesus' divine identity, and thus

\footnotetext{
${ }^{86}$ Ibid., 19.

${ }^{87}$ So S.A. Hunt, The Roman Soldiers at Jesus' Arrest: "You Are Dust, and to Dust You Shall Return,” in S.A. Hunt, D.F. Tolmie, R. Zimmermann, eds., Character Studies in the Fourth Gospel. Narrative Approaches to Seventy Figures in John, WUNT I/314, (Tübingen 2013), 554-67.

${ }^{88}$ Exhaustive criticism of that thesis is submitted by C.R. Sosa Siliezar, Creation, 22.
}

${ }^{89} \mathrm{~F}$. Manns, Le symbolisme du jardin, 70-1, 74; idem, L'Évangile de Jean à la lumière du Judaïsme, SBLA 33, (Jerusalem 1991), 417-8, 422. The name of the

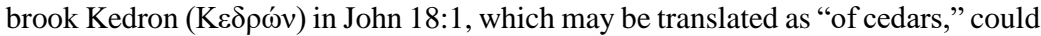
refer to "the cedars in the garden of God" in Ezek 31:8. So, B.P. Robinson, Gethsemane. The Synoptic and the Johannine Viewpoints, Church Quarterly Review 167 (1966): 4-11.

${ }^{90}$ D.F. Ford, Beginning, Ending and Abundance. Genesis 1:1 and the Gospel of John, in D.A. Baer, R.P. Gordon, eds., Leshon Limmudim. Essays on the Language and Literature of the Hebrew Bible, LHBOTS 593, (London 2013), 293. 
indirectly allude to the presence of God in the garden of Eden. ${ }^{91}$ According to R. Zimmermann, Mary Magdalene's recognition of Jesus is prompted by his voice, an allusion to "hearing his voice" in John 10:3.4.27, but also in Gen 3:8.10. God and Jesus, both of whose voices can be heard, "walk" through the garden (Gen 3:8), and in the temple (John 10:23). ${ }^{92}$ This comparison seems entirely implausible, since the sound of God's voice in Paradise causes the first couple to fear and hide themselves, whereas listening to the voice of Jesus guarantees salvation. Additionally, Mary recognised Jesus not so much by his voice (which she had already heard in the words "Women, why are you crying?"), as by having heard her own name. Mariusz Rosik sees a connection between the motifs of knowing in Gen 3:5.22 and of seeking in Gen 3:9, and Mary Magdalene's seeking and knowing the risen Christ (with a reversal in the order of these motifs). In both cases God addresses the persons by their names (Gen 3:9, John 20:16) ${ }^{93}$ The change of verbs connoting Mary Magdalene's manner of seeing ( $\beta \lambda \varepsilon \dot{\pi} \omega-20: 1 ; \theta \varepsilon \omega \rho \varepsilon ́ \omega-20: 12.14$; ó $\alpha \omega-20: 18)$ may be referred to the shift in seeing on the part of Adam and Eve, when their eyes have been opened. ${ }^{94}$ Moreover, Rosik links the prohibition of eating the fruit of the tree of the knowledge of good and evil (Gen 2:16-17; 3:5) with Jesus' prohibition of being touched by Mary Magdalene (John 20:17) ${ }^{95}$; he connects the fact of the first people being dressed by God in garments made of skins (Gen 3:21) with the grave-clothes used in the entombment of Jesus (John 19:40; 20:6-7) ${ }^{96}$; and he finds significant the sword of the paradisiac cherubim (Gen 3:24)

91 J.N. Sanders, B.A. Mastin, A Commentary on the Gospel of St. John, (London 1968), 426; N. Wyatt, Gardener, 38.

92 R. Zimmermann, Symbolic Communication, 231.

${ }_{93}$ M. Rosik, Discovering the Secrets, 87-91.

94 Ibid., 89-90.

95 Ibid., 96: "the breaking of God's prohibition not to eat from the tree of recognition of right and wrong brought death to the man. Mary Magdalene's acting in obedience to Jesus' interdiction ("Do not touch Me!") gives the prospect of life ensuing from the Resurrection" (cf. ibid., 93).

${ }^{96}$ Ibid., 94-5. He explains (95) this inversion of threads in the following way: "In the Garden of Eden, Adam lost his immortality and therefore God covered his nakedness, and so He did not leave the first man totally unprotected; now the new Adam, Christ, returns to life; as a consequence he left behind his burial garments." 
contrasted with the lack of such weapon in the case of the Johannine angels (John 20:12). 97 Our catalog of not-quite-persuasive associations may further be extended with the attempt at interpreting Adam's expulsion $(\dot{\varepsilon} \kappa \beta \alpha \dot{\alpha} \lambda \lambda \omega)$ from Eden in relation to the new

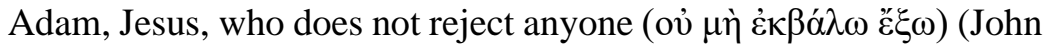
6:37).

\section{Conclusion}

The presence of marked allusions to Gen 1-3 in the Gospel of John, alongside a lack of clearly identified quotations, indicates that the Fourth Gospel gives the creation theme the function of a narrative rather than that of a text. ${ }^{98}$ The creation theme is particularly vibrant at the outset $(1: 1-18)$ and towards the end of the Johannine narrative (20:22). That strong, identified inclusio points to the thematic key that defines the interpretation of the entire Gospel and of the whole ministry of Jesus. At the same time, John opens his Gospel with an allusion to the first sentence of the Torah and of the Bible, suggesting to his readers that his Gospel becomes the new Torah, the new Bible, or at least a fragment, or-more precisely - a continuation of the story told in the Bible. Most of all, by pointed reference to the creation theme he underscores the close relationship between Jesus and the Father, the Creator. Thus, John sees Jesus as a participant in the process of creation, reserved elsewhere exclusively for God the Creator. Christ thus fulfills both the role of God the Creator (Logos in John 1:1-18) and that of the new Adam (the supposed gardener in John 20:15). The status of Jesus, through the evocations of the creation theme, is presented as unique in the entire salvation history, incomparable with any other

\footnotetext{
${ }^{97}$ Ibid., 91-3. The author (96) summarises this point as follows: "the entrance to the closed paradise is guarded by cherubim who were stationed on guard by God in front of Eden to protect access to the tree of life. In front of the open tomb of Jesus there are two angels who by their presence itself announce that the way to life is open again. [...] cherubim in front of Eden's gates are equipped with swords, which symbolize God's punishment over the man. Angels, near the tomb of Jesus, abandoned their swords because man's sin has already been expiated by the Passion of Jesus, and by his Death and Resurrection."

${ }^{98}$ M.J.J. Menken, Genesis, 83-4.
} 
figure (such as Abraham, Moses, or John the Baptist). The creation theme pervading the Gospel of John is therefore indicative of the unity of salvation history, which-having started with the creation by virtue of Logos-finds its fulfilment in the earthly mission of the very same Logos, Jesus Christ (20:22). Compared especially with the writings of St Paul, the motif of Jesus as the new Adam is rendered more subtly in the Gospel of John. Within the Johannine approach, the Messiah, the Creator and the new Adam, continues and completes, or rather renews the work of creation. This work was accomplished in Jesus and through his ministry, but is heralded and carried forth by the community of his disciples, understood as the restored humanity (the new Eve). Reading John's allusions to Gen 1-3 in line with the fulfillment or restoration of creation, one can see that the Evangelist defines the community of the disciples of Jesus as the fullness of creation (the healed humanity). It is the new creation, that was restored in its capacity of remaining in the presence of God, though previously forsaken because of the sin of Adam and Eve. From that perspective, the church constitutes a community that has returned to the long-lost garden of Eden. The ministry of this church, the new humanity, is addressed to every human being, created in the image of God and awaiting the revelation of the creative light of the world.

\section{Bibliography}

Allen D., The Use of Criteria: The State of the Question, in D. Allen, S. Smith, eds., Methodology in the Use of the Old Testament in the New: Context and Criteria, LNTS 579, London 2019, 129-141.

Allison D.C., The New Moses. A Matthean Typology, Edinburgh 1993.

Allo E.-B., L'Évangile sprituel de saint Jean suivi de le Règne de Dieu et le Monde, Paris 1944.

Barrosse T., The Seven Days of the New Creation in St. John's Gospel, The Catholic Biblical Quarterly 21 (1959): 507-16.

Beale G.K., The Eschatological Conception of New Testament Theology, in K.E. Brower, M.W. Elliott (eds.), Eschatology in Bible and Theology. Evangelical Essays at the Dawn of a New Millennium,

Downers Grove, IL 1997, 11-52.

Biguzzi G., Il vangelo dei segni, Studi biblici 175, Brescia 2014. 
Boismard M.-É., L'évangile à quatre dimensions, Lumière 5/1 (1951): 94-114.

Boismard M.-É., Le Prologue de Saint Jean, Lectio Divina 11, Paris 1953.

Boismard M.-É., Lamouille A., L'évangile de Jean, Synopse des quatre Évangiles en français 3, Paris 1977.

Borgen P., Logos Was the True Light. Contributions to the Interpretation of the Prologue of John, Novum Testamentum 14 (1972): 115-30.

Brodie T.L., The Gospel according to John. A Literary and Theological Commentary, New York 1993.

Brown J.K., Creation's Renewal in the Gospel of John, The Catholic Biblical Quarterly 72 (2010): 275-90.

Carmichael C.M., The Story of Creation. Its Origins and Its Interpretation in Philo and the Fourth Gospel, Ithaca 1996.

Coloe M.L., The Structure of the Johannine Prologue and Genesis 1, Australian Biblical Review 45 (1997): 40-55.

Coloe M.L., Theological Reflections on Creation in the Gospel of John, Pacifica 24 (2011): 1-12.

D'Angelo M.R., A Critical Note: John 20:17 and Apocalypse of Moses 31, Journal of Theological Studies 41 (1990): 529-36.

Derrett J.D.M., John 9:6 Read with Isaiah 6:10; 29:9, Evangelical Quarterly 66 (1994): 251-4.

Derrett J.D.M., Miracles, Pools, and Sight: John 9,1-41; Genesis 2,6-7; Isaiah 6,10; 30,20; 35,5-7, Bibbia e Oriente 36 (1994): 71-85.

Droge A.J., Sabbath Work / Sabbath Rest: Genesis, Thomas, John, History of Religions 47 (2007-2008): 112-41.

Endo M., Creation and Christology. A Study on the Johannine Prologue in the Light of Early Jewish Creation Accounts, WUNT 2/149, Tübingen 2002.

Ensor P.W., Jesus and His "Works". The Johannine Sayings in Historical Perspective, WUNT II/85, Tübingen 1996.

Ford D.F., Beginning, Ending and Abundance. Genesis 1:1 and the Gospel of John, in D.A. Baer, R.P. Gordon (eds.), Leshon Limmudim. Essays on the Language and Literature of the Hebrew Bible, LHBOTS 593, London 2013, 292-305.

Frayer-Griggs D., Spittle, Clay, and Creation in John 9:6 and Some Dead Sea Scrolls, Journal of Biblical Literature 132 (2013): 659-70.

Girard M., La structure heptapartite du quatrième évangile, Sciences Religieuses 5 (1975-1976): 350-9.

Goettmann J., Saint Jean. Évangile de la Nouvelle Genèse, Paris 1982. 
Guilding A., The Fourth Gospel and Jewish Worship: A Study of the Relation of St. John's Gospel to the Ancient Jewish Lectionary System, Oxford 1960.

Hambly W.F., Creation and Gospel. A Brief Comparison of Genesis 1,1-2,4 and John 1,1-2,12, in F.L. Cross (ed.), Studia Evangelica. V. Papers Presented to the Third International Congress on the New Testament Studies Held at Christ Church, Oxford, 1965, Berlin 1968, $69-74$.

Hatina T.R., John 20,22 in Its Eschatological Context: Promise or Fulfilment? Biblica 74 (1993): 196-219.

Hays R.B., The Conversation of the Imagination. Paul as Interpreter of Israel's Scripture, Grand Rapids 2005.

Hays R.B., Echoes of Scripture in the Letters of Paul, New Haven 1989.

Hengel M., The Old Testament in the Fourth Gospel, Horizons in Biblical Theology 12 (1990):19-41.

Hoskyns E.C., Genesis I-III and St John's Gospel, The Journal of Theological Studies 21 (1920):210-8.

Humphrey E.M., New Creation, in K.J. Vanhoozer (ed.), Dictionary for Theological Interpretation of the Bible, Grand Rapids 2005, 536-7.

Hunt S.A., The Roman Soldiers at Jesus' Arrest: "You Are Dust, and to Dust You Shall Return”, in S.A. Hunt, D.F. Tolmie, R. Zimmermann (eds.), Character Studies in the Fourth Gospel. Narrative Approaches to Seventy Figures in John, WUNT 314, Tübingen 2013, 554-67.

Jasper A., Interpretative Approaches to John 20,1-18. Mary at the Tomb of Jesus, Studia Theologica 47 (1993): 107-17.

Jauhiainen M., The Use of Zechariah in Revelation, WUNT II/199, Tübingen 2005.

Keener C.S., The Gospel of John. A Commentary, Peabody 2003.

Koch Ch., Geschaffen, um Gott zu sehen. Die Heilung des Blindgeborenen als ,Schöpfungsereignis “ in Joh 9,1-38, in A. Vonach, G. Fischer (eds.), Horizonte biblischer Texte, OBO 196, Göttingen 2003, 195-222.

Kubiś A., The Book of Zechariah in the Gospel of John, Études bibliques 64, Pendé 2012.

Kubiś A., The Old Testament Background of "Ecce Homo" in John 19:5, Biblica et Patristica Thorunensia 11/4 (2018): 495-519.

Kubiś A., Zechariah 6:12-13 as the Referent of $\gamma \rho \alpha \varphi \eta$ in John 2:22 and 20:9. A Contribution to Johannine Temple-Christology, The Biblical Annals 2 (2012): 153-94.

Kubiś A., Znaczenie pozycji aniołów $w$ grobie Jezusa w J 20,12, The Biblical Annals 6 (2016): 459-93. 
Lindars B., The Gospel of John, The New Century Bible Commentary, Grand Rapids-London 1972.

Litwa M.D., Behold Adam. A Reading of John 19:5, Horizons in Biblical Theology 32 (2010): 129-43.

Madden P.J., Jesus' Walking on the Sea. An Investigation of the Origin of the Narrative Account, BZAW 81, Berlin 1997.

Manns F., L'Évangile de Jean à la lumière du Judaïsme, SBLA 33, Jerusalem 1991.

Manns F., Le symbolisme du jardin dans le récit de la passion selon St Jean, Liber Annuus 37 (1987): 53-80.

Mariano C., Tetelestai. Il significato della morte di Gesù alla luce del compimento della Scrittura in Gv 19,16b-37, Quaderni della rivista di scienze religiose 14, Roma 2010.

Mateos J., Barreto J., Dizionario teologico del Vangelo di Giovanni, Assisi 1982.

Mateos J., Barreto J., El Evangelio de Juan. Análisis lingüístico y comentario exegético, Lectura del Nuevo Testamento 4, Madrid 1982.

McDonough M., Christ as Creator. Origins of a New Testament Doctrine, Oxford 2009.

McHugh J.F., A Critical and Exegetical Commentary on John 1-4, The International Critical Commentary, London 2009.

Menken M.J.J., Genesis in John's Gospel and 1 John, in S. Moyise, M.J.J. Menken (eds.), Genesis in the New Testament, LNTS 466, London 2012, 83-98.

Minear P.S., Christians and the New Creation. Genesis Motifs in the New Testament, Louisville 1994.

Mlakuzhyil G., The Christocentric Literary Structure of the Fourth Gospel. Second Enlarged Edition, Analecta biblica 117, Rome 2011.

Moore A.M., Signs of Salvation. The Theme of Creation in John's Gospel, Cambridge 2013.

Painter J., Earth Made Whole. John's Rereading of Genesis, in J. Painter R.A. Culpepper, F.F. Segovia (eds.), Word, Theology, and Community in John, St. Louis 2002, 65-84.

Phillips T.E., ,, The Third Fifth Day?” John 2:1 in Context, Expository Times 115 (2004): 328-31.

Phythian-Adams W.J., The New Creation in St. John, Church Quarterly Review 144 (1947): 52-75.

Piekarz D., “A świattość w ciemności świeci... ”. Konfrontacja świattości z ciemnościa w Ewangelii Janowej, Verbum Vitae 29 (2016): 251-69. 
Quiévreux F., La structure symbolique de l'Évangile de Saint Jean, Revue d'histoire et de philosophie religieuses 33/2 (1953): 123-65.

Reinhartz A., To Love the Lord. An Intertextual Reading of John 20, in F.C. Black, R. Boer, E. Runions (eds.), The Labour of Reading. Desire, Alienation, and Biblical Interpretation, SBL Semeia Studies 36, Atlanta 1999, 53-69.

Richard E., Expressions of Double Meaning and Their Function in the Gospel of John, New Testament Studies 31 (1985): 69-112.

Robinson B.P., Gethsemane. The Synoptic and the Johannine Viewpoints, Church Quarterly Review 167 (1966): 4-11.

Rosik M., Discovering the Secrets of God's Gardens. Resurrection as New Creation (Gen 2:4b-3:24; Jn 20:1-18), Liber Annuus 58 (2008): 81-98.

Rosner B.S., Paul, Scripture and Ethics: A Study of 1 Corinthians 5-7, AJEC 22, (Leiden 1994).

Sanders J.N., Mastin B. A., A Commentary on the Gospel of St. John, London 1968.

Saxby H., The Time-Scheme in the Gospel of John, Expository Times 104 (1992): 9-13.

Schaper J., The Messiah in the Garden. John 19.38-41, (Royal) Gardens, and Messianic Concepts, in M. Bockmuehl, G.G. Stroumsa (eds.), Paradise in Antiquity. Jewish and Christian Views, Cambridge 2010, 17-27.

Serra A., Contributi dell'antica letteratura giudaica per l'esegesi di Giovanni 2, 1-12 e 19, 25-27, Scripta Pontificiae Facultatis Theologicae «Marianum» 31, Roma 1977.

Serra A., ,, Vi erano la sei giare...”. Gv 2,6 alla luce di antiche tradizioni giudaico-cristiane relatie ai ,sei giorni" della creazione, in Nato da Donna... (Gal 4,4). Ricerche bibliche su Maria di Nazaret (1989-1992), Roma-Milano 1992, 141-88.

Simoens Y., Selon Jean, Collection IET 17, Bruxelles 1997.

Skehan P.W., The Date of the Last Supper, Catholic Biblical Quarterly 20 (1958): 192-9.

Sosa Siliezar C.R., Creation Imagery in the Gospel of John, LNTS 546, London 2015.

Stamm R.T., Creation and Revelation in the Gospel of John, in J.M. Myers (ed.), Search the Scripture: New Testament Studies in Honor of Raymond T. Stamm, Leiden 1969, 13-32.

Strauss D.F., The Life of Jesus Critically Examined, London 1898.

Suggit J.N., Jesus the Gardener. The Atonement in the Fourth Gospel as Re-creation, Neotestamentica 33 (1999): 161-8. 
Terian A., Creation in Johannine Theology, in L. Miller (ed.), Good News in History. Essays in Honor of Bo Reicke, Atlanta 1993, 45-61.

Thompson M.B., Clothed with Christ. The Example and Teaching of Jesus in Romans 12.1-15.13, JSNT.S 59, Sheffield 1991.

Thompson M.M., The Breath of Life. John 20:22-23 Once More, in G.N. Stanton, B.W. Longenecker, S.C. Barton (eds.), The Holy Spirit and Christian Origins, Grand Rapids 2004, 69-78.

Thompson M.M., "Light" ( $\varphi \tilde{\omega} \varsigma)$ : The Philosophical Content of the Term and the Gospel of John, in J.G. van der Watt, R.A. Culpepper, U. Schnelle, eds., The Prologue of the Gospel of John: Its Literary, Theological and Philosophical Contexts, WUNT 359, Tübingen 2016, 273-83.

Trudniger L.P., The Seven Days of the New Creation in St. John's Gospel: Some Further Reflections, Evangelical Quarterly 44 (1972): 154-9.

Van Belle G., Double Entendre in the Gospel according to John, in G. Van Belle, J.G. van der Watt, P. Maritz (eds.), Theology and Christology in the Fourth Gospel. Essays by the Members of the SNTS Johannine Writings Seminar, BETL 184; Leuven 2005, 463-81.

Van Diemen P., La semaine inaugurale et la semaine terminale de l'Évangile de Jean. Message et structures, doctoral dissertation, Rome 1972.

Vignolo R., La morte di Gesù nel Quarto Vangelo come compimento, in G. Ghiberti (ed.), Opera Giovannea, Logos. Corso di studi biblici 7, Torino 2003, 273-92.

Voortman T.C., Understanding the Fourth Gospel from the Perspective of the Creation Theme, doctoral dissertation, Rand Afrikaans University, 1998.

Weidemann H.U., The Victory of Protology Over Eschatology? Creation in the Gospel of John, in T. Nicklas, K. Zamfir (eds.), Theologies of Creation in Early Judaism and Ancient Christianity, DCLS 6, Berlin 2010, 299-334.

Widengren G., The King and the Tree of Life in Ancient Eastern Religion (King and Saviour IV), UUA 1951/4, Uppsala-Leipzig 1951.

Willemse J., Het vierde evangelie. Eeen onderzoek naar zijn structuur, Hilversum-Anwerpen 1965.

Witherington B., New Creation or New Birth? Conversation in the Johannine and Pauline Literature, in Conversation in the Wesleyan Tradition, in K.J. Collins, J.H. Tyson (eds.), Nashville 2001, 119-42.

Wojciechowski M., Le don de L'Esprit Saint dans Jean 20.22 selon Tg. Gn. 2.7, New Testament Studies 33 (1987): 289-91. 
Wright N.T., Resurrection and the Renewal of Creation, The Biblical Annals 9/4 (2019): 655-70.

Wyatt N., 'Supposing Him to Be the Gardener' (John 20,15). A Study of the Paradise Motif in John, Zeitschrift für die neutestamentliche Wissenschaft 81 (1990): 21-38.

Zimmermann R., Symbolic Communication between John and His Reader. Garden Symbolism in John 19-20, in T. Thatcher, S.D. Moore (eds.), Anatomies of Narrative Criticism. The Past, Present, and Futures of the Fourth Gospel as Literature, SBLRBS 55, Atlanta 2008, 221-35. 